\title{
Musik Bambu Wiragawi: Representasi Komodifikasi Bambu dari Hasil Strukturasi di Tiga Locus
}

\author{
Komarudin ${ }^{1}$, Lalan Ramlan ${ }^{2}$, Meiga Fristya Laras ${ }^{3}$, Asep Ganjar Wiresna ${ }^{4}$, Asep Saepudin ${ }^{5}$ \\ 1,2,3,4 Institut Seni Budaya Bandung, Indonesia \\ ${ }^{5}$ Institut Seni Indonesia Yogyakarta, Indonesia
}

\begin{abstract}
Wiragawi Bamboo Music: the Representation of Commodification of Bamboo from the Structural Results at Three Locus. The purpose of this study is to describe the results of the commodification of Wiragawi Bamboo Music as a Representation of Structuring in Three Locus, among others, in West Java Province, Yogyakarta Special Region (DIY), and East Nusa Tenggara (NTT). This study uses a qualitative method with a deeper socio-cultural structuration, represented as a work in the form of commodification of bamboo as a musical instrument. The commodification of bamboo as a participatory of 'bamboo body grows' can legitimize an identity and regional authenticity as a form of cultural resilience based on a cultural economy. Bamboo plays an essential role in the cultural process, from birth to death according to its era, so it can be said that bamboo and humans have a close correlation, according to the locus of the area. Research findings include producing a set of Wiragawi bamboo musical instruments as a result of the commodification of bamboo music at three locuses, namely West Java Province, Yogyakarta Special Region (DIY), and East Nusa Tenggara (NTT). The conclusion shows that the primary material of bamboo is still very open to being a source of inspiration in creativity, mainly to produce various new instruments according to the interests and developments of the era.
\end{abstract}

Keywords: bamboo; bamboo music; ancient manuscripts; revitalization; commodification

\begin{abstract}
ABSTRAK
Tujuan penulisan ini untuk mendeskripsikan hasil komodifikasi Musik Bambu Wiragawi sebagai Representasi Dari Strukturasi Di Tiga Locus antara lain di Provinsi Jawa Barat, Daerah Istimewa Yogyakarta (DIY), dan Nusa Tenggara Timur (NTT). Penelitian ini menggunakan metode kualitatif dengan pendalaman strukturasi sosial budaya yang direpresentasikan menjadi sebuah karya berupa komodifikasi bambu sebagai instrumen musik. Komodifikasi bambu sebagai partisipatoris 'tubuh bambu tumbuh', yang dapat melegetimasi sebuah identitas serta otentisitas daerah sebagai bentuk ketahanan budaya berbasis ekonomi kultural. Bambu memegang peranan penting dalam proses kebudayaan, dari mulai proses kelahiran sampai dengan kematian sesuai zamannya sehingga dapat dikatakan bahwa bambu dan manusia memiliki kolerasi yang erat, sesuai dengan locus daerahnya. Temuan penelitian antara lain dihasilkannya seperangkat instrumen musik bambu Wiragawi sebagai hasil komodifiksi dari musik bambu di tiga locus yaitu Provinsi Jawa Barat, Daerah Istimewa Yogyakarta (DIY), dan Nusa Tenggara Timur (NTT). Hasil kesimpulan menunjukkan bahwa bahan dasar bambu masih sangat terbuka peluangnya untuk dijadikan sumber inspirasi dalam berkreativitas terutama untuk menghasilkan berbagai instrumen baru sesuai dengan kepentingan dan perkemangan zamannya.
\end{abstract}

Kata kunci: bambu; musik bambu; naskah kuno; revitalisasi; komodifikasi

\footnotetext{
Alamat korespondensi: Komarudin, Institut Seni Budaya Indonesia (ISBI) Bandung, Jalan Buah Batu No. 212 Bandung. E-mail: komarudin@isbi.ac.id; HP.: 08122436350.
} 


\section{Pendahuluan}

Bambu memegang peranan penting dalam mata rantai tumbuhan, juga merupakan salah satu tanaman dengan pertumbuhan paling cepat di dunia. Di berbagai penjuru belahan dunia, bambu memiliki aspek filosofis dalam beberapa kebudayaan bangsa, termasuk di Indonesia. Sebagai salah satu aspek dalam unsur kebudayaan dan kepercayaan masyarakat juga dapat ditemui dalam masyarakat lebih luas. Bagi masyarakat Sunda, bambu dikenal dengan peristilahaan atau nama awi yang dalam 'A Dictionary of the Sunda Languange of java' yang terbit pertama kali tahun 1841 (Rigg, 1986) menerangkan, sebagai berikut:

Awi, a bambu, a general name for every variety of Bambusa. The Sunda people distinguish the following variete Awi Apus, resembles Awi Tali, and is used much for aplitting into withes; Awi Ater, Strong and good substantial, good for posts; Awi Bitung, large and subtantial, good for post; Bongkonol, small like Tamian, of little use; Awi Buluh, large but subject to be enten by worma; Awi Buluh munti, resemble buluh, and is of little use, Awi Bunar, large, good bambu; Awi Changkeuteuk, smaal sized tubes, makes neat bilik; Awi Awi changkore, a useless variety, cannot stand of itself, but reposes upon other bushes.

Sejak tahun 1841 eksitensi bambu sudah dipergunakan sebagai penompang utama terhadap masyarakat suku Sunda, mulai dari proses kelahiran hingga proses pemakaman masyarakat suku Sunda, baik itu peralatan rumah tangga, permainan, alat musik, tongkat, sampai makanan menjadi penompang dalam kehidupan masyarakat Sunda. Sebagai salah satu etnis terbesar di Indonesia, bahkan di asia tenggara, masyarakat Jawa memiliki berbagai filosofi hidup yang berkaca dari alam sekitar, seperti pohon bambu yang tak luput dari analogi falsafah Jawa 'Ngelmu Pring' (belajar dari bambu) yang merupakan salah satu gambaran karakteristik orang Jawa. 'Ora gampang tugel, merga iso melur...', (tak mudah patah, karena lentur).

Bagi masyarakat Jawa, sifat bambu diyakini memiliki makna 'Urip kuwi ojo podo kaku, meluro lan pasraho. Ojo mangu-mangu, nging terus mlaku.'.
Dalam menjalani hidup jangan menjadi orang yang kaku, bersikaplah lentur atau fleksibel dalam artian kita selalu bersikap terbuka dan membuka diri serta berpangku tangan, terus berjalan, berusaha dan berdoa agar hidup selalu dalam lindungan Tuhan yang mengatur seluruh hidup kita.

Terdapat banyak falsafah yang menjadi rujukan idiologi-idiologi yang tertanam dalam pemikiran masyarakat. Idiologi tersebut fenomenanya dipakai sebagai nilai spiritual yang menjadi landasan untuk diteliti, direvitalisasi, dan dikomodifikasi menjadi sebuah sub-sub nilai capital untuk membentuk pertahanan budaya-dijadikan pendeskripsian, baik berupa karya tulis maupun karya seni yang seharusnya menjadi unsur nilai kebhinekaanpengkemasan destinasi wisata seni pertunjukan berbasis culture study.

Bersandar pada potensi besar dari kebudayaan dan alam inilah, peneliti menganalisis pemanfaatan bambu dalam kehidupan masyarakat untuk dijadikan landasan konsep perancangan musik bambu dengan mengambil sampling pada komunitas masyarakat yang dipandang memiliki tradisi dan budaya bambu yang cukup kuat (dalam balutan cerita rakyat) di 3 (tiga) daerah, yaitu di Provinsi Jawa Barat, Daerah Istimewa Yogyakarta (DIY), dan Nusa Tenggara Timur (NTT). Ketiga daerah tersebut merupakan penghasil bambu dari salah satu kekayaan alamnya, juga kaya akan cerita rakyat (naskah kuno) terutama yang berkaitan dengan mitologi bambu.

Unsur-unsur revitalisasi budaya dan seni tentunya dikomodifikasi untuk dapat diterima di berbagai kalangan, terutama menjadi destinasi wisata seni pertunjukan berbasis ekonomi. Art and culture. (Mosco, 2009) telah menjelaskan, bahwa "Proses mengubah barang dan jasa termasuk komunikasi, menjadi komoditas yang dinilai karena apa yang akan diberikan di pasar". Hal tersebut perlu dilakukan, karena proses elaborasi terus terjadi pada era revolusi Industri 4.0, sehingga menjadi keuntungan sebagai eksistensi destinasi wisata bambu berbasis art and culture.

Bambu sebagai objek pemasaran berbasis destinasi wisata seni pertunjukan yang mempunyai nilai ekonomi, tentunya harus mengandung unsur-unsur estetika yang ada kaitannya dengan 
locus masyarakat tersebut (history), dengan merekontruksi dan/atau mendekonstruksi tanpa menghilangkan esensi budayanya. Edukasi dan sastra menjadi sorotan utama untuk memberikan stimulus dalam pelestarian dan pengembangannya, sehingga diperlukan pendeskripsian melalui ranah edukasi berupa jurnal bereputasi serta mediamedia lainnya sebagai teknik komodifikasi berbasis edukasi. Tidak terhenti hanya sampai di situ, sebab sektor yang akan dikembangkan sampai menyentuh pula produk-produk hasil buah tangan masyarakat berupa; kerajinan (kriya), craft, instrumen, skill (seni), serta produk-produk budaya masyarakat setempat melalui pembinaan yang intensif.

Berangkat dari pernyataan di atas, maka komodifikasi ini menghasilkan model seperangkat ensemble berbahan dasar bambu. Tulisan ini mempertanyakan bagaimana representasi komodivikasi bambu dari hasil strukturasi di tiga locus tersebut, penelitian Jawa Barat (selaawi, Kecamatan selaawi, Garut), Jawa Tengah (Gunung kidul, Wonosobo), Nusa Tenggara Barat (Desa Ratu lodong, Kecamatan Tanjung Bunga, Desa lamaole Solor Barat) dapat terwujud?

\section{Metode Penelitian}

Model penelitian yang digunakan dalam penelitian ini mengarah kepada revitalisasi dan komodifikasi seni budaya. Bentuk musik bambu hasil adaptasi dari naskah kuno, merupakan ungkapan pengalaman anggota komunitas masyarakat yang dipandang memiliki tradisi bambu yang cukup kuat. Potensi kebudayaan yang dimiliki di 3 (tiga) daerah ini, yaitu; di Provinsi Jawa Barat, Yogyakarta dan Nusa Tenggara Timur (NTT) sangat berpotensi untuk dikembangankan menjadi objek wisata berbasis sumber daya alam, seni dan budaya.

Pengalaman-pengalaman sarat dengan ungkapan nilai-nilai simbolis, disampaikan dalam model revitalisasi dan komodifikasi seni yang berupa gerak, lagu, wacana, dan habit daerah tersebut, sehingga mengandung nilai sebagai suatu kesatuan yang sudah teranam dan larut dalam keyakinan masyarakat setempat yang dapat mempengaruhi jiwa penonton atau masyarakat.
Untuk mengungkap simbol-simbol dalam pertunjukan berupa musik, lagu, maupun gerak tari, salah satunya dengan menerapkan metode fenomenologi. Metode penelitian fenomenologi yang secara inten fenomenologi dicetuskan pertama kali sebagai kajian filsafat oleh (Edmund Husserl, 1972) yaitu "merupakan jenis metode penelitian kualitatif yang diaplikasikan untuk mengungkap kesamaan makna, esensi dari suatu konsep kejadian".

Dalam mengungkap esensi makna tersebut, fenomenologi menjadi metode riset yang penerapannya berhubungan dengan filsafat, filosofis, dan psikologi. Abstraksi dan refleksi filosofis kerap dipraktikkan oleh para peneliti dalam rangka menangkap maksud dari informan sebelum diuraikan dalam narasi yang mendalam. Fenomenologi merupakan studi dalam bidang filsafat yang mempelajari manusia sebagai sebuah fenomena. Fenomonologi sebagaimana diungkapkan oleh Johann Heinrich Lambert (1728 -1777), seorang filsuf Jerman dalam bukunya Neues Organon 1764 (Hasbiansyah, 2005) yaitu, bahwa "dalam filsafat pada umumnya dikaitkan dengan hermeneutika, yaitu ilmu yang mempelajari makna dari fenomena”.

Salah satu poin penting yang menjadi kelebihan studi fenomenologis ialah pengalaman yang tersembunyi di dalam aspek filosofis dan psikologis individu dapat terungkap melalui narasi, sehingga peneliti dan pembaca seolah dapat mengerti pengalaman hidup yang dialami oleh subjek penelitian. Tujuan dari penelitian fenomenologis ialah mereduksi pengalaman individual terhadap suatu fenomena ke dalam deskripsi yang menjelaskan tentang esensi universal dari fenomena tersebut. Fenomenolog berupaya memahami esensi dari suatu fenomena.

Dalam proses modifikasi musik bambu, dilakukan lima langkah antara lain: Pertama; Peneliti memastikan bahwa rumusan masalah yang dibuat relevan untuk diteliti dengan pendekatan fenomenologis. Rumusan masalah penelitian yang relevan dengan menerapkan fenomenologi, merupakan hal penting untuk memahami ruang anggota komunitas masyarakat, yang dipandang memiliki tradisi bambu yang cukup kuat, serta potensi kebudayaan dari 3 (tiga) locus. 
Kedua; Peneliti menangkap fenomena untuk dipertanyakan maknanya bagi sekelompok individu yang mengalaminya. Seperti, anggota komunitas masyarakat yang dipandang memiliki tradisi bambu yang cukup kuat, serta potensi kebudayaan yang dimiliki dari 3 (tiga) daerah di antaranya, Provinsi Jawa Barat; Daerah Istimewa Yogyakarta; dan Nusa Tenggara Timur (NTT).

Ketiga; Data fenomenologis berupa narasi deskriptif yang dikumpulkan dari cerita seniman, pengrajin, tokoh masyarakat yang mengalami suatu fenomena kebudayaan, sumberdaya alam (bambu) maupun mengenai pariwisata. Data riset fenomenologis diperoleh melalui perumusan hasil observasi dan wawancara di komunitas masyarakat yang dipandang memiliki tradisi bambu yang cukup kuat,

Keempat; Proses analisis data pada prinsipnya mirip dengan analisis kualitatif lainnya, yaitu data ditranskrip, lalu dengan merujuk pada rumusan masalah, peneliti melakukan coding, clastering, labelling secara tematik dan melakukan interpretasi ke dalam bentuk instrumen musik yang dihasilkan dari perumusan observasi, wawancara, disandingkan dengan studi pustaka mengenai budaya dan tradisi bambu di lingkungan masyarakat,

Kelima; Masing-masing tema yang muncul dalam proses analisis mengandung narasi verbatin (teks sesuai dengan apa yang diucapkan oleh informan). Secara garis besar berupa deskripsi tekstual tentang apa yang dialami oleh seniman, pengrajin, tokoh masyarakat dan bagaimana mereka mengalaminya. Dari deskripsi tekstual yang didokumentasi audio visual menjadi sebuah bahan peneliti untuk mendeskripsikan esensi universal dari fenomena tradisi bambu serta potensi kebudayaan. Fenomenologi berkonsentrasi pada pengalaman pribadi termasuk bagian dari individuindividu yang ada saling memberikan pengalaman satu sama lainnya.

Pada dasarnya fenomenologi adalah suatu tradisi pengkajian yang digunakan untuk mengeksplorasi pengalaman manusia. Dalam konteks ini ada asumsi bahwa manusia aktif memahami dunia disekelilingnya sebagai sebuah pengalaman hidupnya dan aktif menginterpretasikan pengalaman tersebut. Maka, revitalisasi dan komodifikasi seni untuk tercapainya ketahanan budaya perlu dilakukan sebuah strategi dengan melakukan peningkatan keinovasian berbasis lokalitas. Strategi ini dengan menggunakan pendekatan multidisiplin (seni pertunjukan, cultural studies, dan industri/ekonomi kreatif). Pemaknaan dilakukan secara semiotis dengan melihat hubungan antar data untuk mendapatkan simpulan secara komprehensif. Teknik analisis data fenomenologi untuk memahami realitas sosial masyarakat yang memiliki potensi sumber daya alam jenis bambu dengan kawasan perhutanan sosial, serta daerah yang memiliki kebudayaan cerita rakyatnya.

Ekspresi-ekspresi dari realitas sosial di tiga daerah yaitu Jawa Barat, Daerah Istimewa Yogyakarta (DIY) serta Nusa Tenggara Timur (NTT) ini disuling menjadi makna dengan cara melakukan interpretasi induktif untuk mencapai kualitas estetis. Cerita rakyat dan relasi musikal bambu menjadi hal yang sangat berperan penting. Selanjutnya penelitian ini dapat menjadi acuan capaian estetis dalam pertunjukan musik bambu di Indonesia. Kegiatan tersebut sekaligus berdampak pada pemberdayaan masyarakat, peningkatan kesejahteraan, dan kemandirian masyarakat.

\section{Sistem Komodifikasi Musik}

Untuk menjalankan strategi dalam merevitalisasi dan memodifikasi seni sebagai ketahanan budaya yang difokuskan pada inovasi berbasis lokalitas dengan pendekatan paradigma multidisiplin (seni pertunjukan, cultural studies, dan industri/ekonomi kreatif) yang meng-arah pada pemaknaan secara semiotis yaitu melihat hubungan antar data untuk mendapatkan simpulan secara komprehensif, maka diperlukan suatu sistem yang selaras agar dapat menghasilkan capaian yang optimal, yaitu Komodifikasi Musik Bambu dari Hasil Strukturasi di Tiga Locus.

Penelitian dilakukan dengan tiga tahapan antara lain:

1. Perencanaan penelitian:

a. Menentukan komunitas masyarakat yang dipandang memiliki tradisi bambu yang cukup kuat (bulan Juni 2021); 
b. Studi pustaka mengenai budaya dan tradisi bambu di lingkungan masyarakat (Juni 2021).

2. Pelaksanaan penelitian:

a. Penelitian lapangan di tiga komunitas: Sunda (Jawa Barat), Jawa (D.I. Yogyakarta, dan NTT (Oktober 2021);

b. Menentukan formulasi dan bentuk instrumen, berdasarkan referensi hasil penelitian (Oktober 2021).

3. Pembuatan intrumen musik bambu Wiragawi.

\section{Hasil dan Pembahasan}

Indonesia dikenal memiliki kekayaan budaya dengan segala keanekaragaman dan keunikannya. Kebudayaan tersebut merupakan akumulasi proses interaksi yang bersejarah dengan lingkungan sosial dan lingkungan alamnya melalui berbagai media. Interaksi tersebut meninggalkan jejaknya dalam bentuk peninggalan tertulis (prasasti, lontar/ babad, sumber kesusastraan tradisional lain), dan warisan budaya dalam bentuk tidak tertulis. Di antara warisan budaya tak tertulis ada dalam bentuk Bambu yang bersifat monumental. Warisan budaya tersebut hingga kini masih dipelihara dan difungsikan oleh masyarakat sekitarnya sebagai Living Monument Bamboo.

Warisan budaya merupakan kekayaan budaya (cultural capital) yang mempunyai nilai penting bagi pemahaman dan pengembangan sejarah, ilmu pengetahuan dan kebudayaan dalam kerangka memupuk keperibadian masyarakat dan bangsa. Namun perkembangan iptek yang sangat pesat yang disertai dengan pertumbuhan penduduk yang cukup cepat dan kegiatan industri dalam pembangunan, menimbulkan perubahan-perubahan yang kurang terkendali sehingga dapat membahayakan dan mengancam kelestarian berbagai kekayaan budaya tersebut serta lingkungannya.

Warisan budaya dan sumberdaya alam yang semakin terancam oleh kerusakan, bukan saja oleh sebab tradisional, tetapi juga oleh karena perubahan sosial dan kondisi sosial ekonomi yang semakin memperburuk situasi dan sebagai fenomena yang hebat mengenai kerusakan atau pengerusakan
(Unesco, 1999). Ketika sumberdaya tersebut sudah rusak atau hilang, kesadaran umumnya selalu datang terlambat bahwa kita telah kehilangan suatu yang sangat penting artinya dalam kehidupan, khususnya dalam pembangunan mental, spiritual atau kepribadian dan bahkan untuk pembangunan sosial ekonomi.

Oleh karena itu, untuk mencegah dan mengurangi terjadinya kerusakan dan pengerusakan warisan budaya dan lingkungannya, perlu dilakukan pengelolaan sumberdaya (living monument dan lingkungannya) secara proaktif agar tidak tejadi pemiskinan budaya. Pengelolaan dapat dilakukan melalui berbagai pendekatan terpadu untuk menjaga kelestarian dan keseimbangan sosial ekonomi, budaya, dan ekologi dalam nuansa pembangunan yang berkelanjutan.

Terkait dengan pemahaman budaya sebagai mekanisme adaptasi hidup, (Spradley, 1997) menyatakan, budaya adalah sistem pengetahuan yang diperoleh manusia melalui proses belajar yang mereka gunakan untuk mengiterpretasikan dunia sekelilingnya dan sekaligus untuk menyusun strategi perilaku dalam menghadapai dunia sekitarnya. Pada sisi yang lain, terkait dengan hubungan manusia (budaya) dengan lingkungannya, (Bakkers SJ, 1989) menyatakan, alam sekitar tidak hanya memberikan corak lahir kepada kebudayan, melainkan juga mempengaruhi pola pikiran, menentukan perasaan, perangai dan kesenian. Lebih lanjut dinyatakan, dalam daerah sukar atau banyak tantangan alam, kebudayaan merupakan simbiose antara manusia dan alam. Faktor-faktor kebudayaan membentangkan in-teraksi dan interplay antara manusia dan alam yg begitu kompleks. Sementara itu yang terkait dengan hubungan dialektik antara budaya dengan lingkungannya, dinyatakan (Rossle M. And Cleere, 2001):

"the combine works of nature and mankinds,
they express a long and intimate relationship
between people and their environment.
Certain sites reflect specipic techniques of
land use that protect and enhence biological
diversity. Other are associated with powerful
beliefs and artistic and traditional customs,
and embody an exceptional spiritual
relationship of people with nature".

"the combine works of nature and mankinds, they express a long and intimate relationship between people and their environment. Certain sites reflect specipic techniques of land use that protect and enhence biological diversity. Other are associated with powerful beliefs and artistic and traditional customs, and embody an exceptional spiritual relationship of people with nature". 
Pernyatan tersebut menunjukkan alam dan budaya saling mempengaruhi secara intim. Keterkaitan hubungan budaya dengan lingkungan alam (bentang lahan) ini lazimnya dikenal dengan cultural landscape.

\section{Mitologi}

Bambu tergolong keluarga Gramineae (rumput-rumputan) disebut juga Giant Grass (rumput raksasa), berumpun dan terdiri dari sejumlah batang (buluh) yang tumbuh secara bertahap, dari mulai rebung, batang muda dan sudah dewasa pada umur 4-5 tahun. Batang bambu berbentuk silindris, berbuku-buku, beruas-ruas berongga kadangkadang masif, berdinding keras, pada setiap buku terdapat mata tunas atau cabang. Akar bambu terdiri atas rimpang (rhizon) berbuku dan beruas, pada buku akan ditumbuhi oleh serabut dan tunas yang dapat tumbuh menjadi batang.

Berdasarkan jenisnya yang kurang lebih berjumlah 1.500 species bambu dalam 80 negara, sekitar 200 species dari 20 negara ditemukan di Asia Tenggara (Dransfield; E.A. Widjaya, 1995), sedangkan di Indonesia ditemukan sekitar 147 jenis. Tanaman bambu Indonesia ditemukan di dataran rendah sampai pegunungan dengan ketinggian sekitar $300 \mathrm{~m}$ dpl. Pada umumnya ditemukan ditempat-tempat terbuka dan daerahnya bebas dari genangan air. (Dove, 1985), (Colletta, 1987), dan (Kusumaatmadja, 1995) menambahkan, bahwa kajian maupun pemahaman terhadap kearifan tradisional baik berbentuk sistem budaya maupun sistem sosial yang berkembang dalam suatu masyarakat amat bermanfaat.

Kemanfaatannya tidak semata-mata bagi penambahan pengetahuan tentang kebudayaan maupun ekologi yang berkembang pada suatu komunitas, tetapi bisa pula dipakai sebagai sumberdaya atau acuan bagi pembangunan baikyang ditujukan terhadap masyarakat yang bersangkutan, ataupun masyarakat lain yang memiliki kesamaan latar belakang sistem sosiokultural. Bahkan (Kusumaatmadja, 1995) menekankan pentingnya "pemahaman tentang kearifan tradisional sebagai kebutuhan yang mendesak karena adanya kenyataan bahwa kemajuan ilmu pengetahuan dan teknologi acapkali menimbulkan ancaman bagi kelestarian lingkungan”.

Teori AGIL Talcott Parson. Konsep AGIL merupakan pengembangan teori fungsionalisme struktural dengan berpegang pada empat persyaratan mutlak yang harus dicukupi oleh setiap masyarakat, kelompok atau organisasi (Damsar, 2015). Bila tidak ada, maka sistem sosial tersebut tidak akan bertahan dan harus berakhir. Fungsi dari keempat persyaratan Parson diartikan sebagai suatu kegiatan yang diarahkan kepada pencapaian kebutuhan dari suatu sistem. Keempat persyaratan tersebut adalah sebagai berikut:

a. Adaptasi (adaptation), yakni supaya masyarakat dapat bertahan mereka harus mampu menyesuaikan diri dengan lingkungan dan mengubah lingkungan agar dapat sesuai dengan masyarakat. Adaptasi menunjuk pada keharusan bagi sistem sosial untuk menghadapi lingkungan;

b. Tujuan (goal), artinya sistem harus mampu menentukan tujuan dan berusaha untuk mencapai tujuan yang telah dirumuskan. Tujuan yang diutamakan adalah tujuan tujuan bersama anggota dalam sistem sosial, bukan tujuan individu;

c. Integrasi (Integration), yakni masyarakat harus mengatur hubungan di antara komponenkomponennya agar dapat berfungsi secara maksimal. Sosialisasi mempunyai kekuatan integratifyang sangat tinggi dalam mempertahankan kontrol sosial untuk menghindari konflik yang merusak;

d. Latensi (latency) atau pemilihan pola-pola yang sudah ada (pattern maintance), yakni setiap masyarakat harus mempertahankan, baik motivasi individu maupun pola budaya yang menciptakan dan mempertahankan motivasinya. Latensi menunjuk pada kebutuhan mempertahankan nilai-nilai dasar serta norma yang dianut bersama oleh para anggota masyarakat.

Melalui penggunaan konsep AGIL dapat dipahami latar belakang dan strategi yang dapat dilakukan masyarakat dalam pelestarian terhadap bambu. Pemertahanan bambu yang dapat dilakukan oleh masyarakat bukanlah tanpa alasan. Berbagai gagasan, pola tata kelakukan maupun benda-benda yang dihasilkan dari keberadaan bambu dilatarbelakangi adanya landasan ideologi 
yang secara ajeg dirawat dari masa ke masa. Istilah ideologi dalam kajian budaya menurut (Cavallaro, 2004) adalah,

Sekumpulan ide, cita-cita, nilai atau kepercayaan; filsafat; agama; nilai-nilai palsu yang digunakan untuk mengendalikan seseorang; seperangkat kebiasaan atau ritual; suatu media tempat sebuah budaya membentuk dunianya; ide-ide yang diunggulkan oleh kelas sosial, gender atau kelompok ras tertentu; nilai-nilai yang melanggengkan struktur kekuasaan dominan; suatu proses di mana sebuah budaya memproduksi makna dan peranperan bagi subjek-subjeknya; gabungan antara budaya dan bahasa; perwujudan konstruksi budaya sebagai kenyataan yang sesungguhnya.

Dengan demikian ideologi dapat didefinisikan baik secara netral, sebagai perangkat ide tanpa konotasi-konotasi politis yang jelas/terang-terangan, maupun secara kritis, sebagai seperangkat ide melalui mana orang membiasakan dirinya sendiri dan orang lain dalam konteks sosio-historis yang spesifik, dan melalui mana kemakmuran kelompok tertentu dikedepankan.

Definisi tentang ideologi tersebut di atas memberikan pemahaman bahwa melalui ideologi, masyarakat atau individu dapat dibentuk kepercayaannya tentang sesuatu sehingga dijadikan acuan untuk mengendalikan maupun memapankan kebiasaan-kebiasaan tertentu. Melalui makna yang serupa (Kutha Ratna, 2005) mengemukakan definisi ideologi sebagai,

Sistem berpikir, sistem kepercayaan yang berkaitan dengan tindakan-tindakan sosial dan politik. Dalam perkembangan berikutnya, ideologi lebih banyak dihubungkan dengan asimetri kekuasaan, dengan pembenaran dominasi. Makna terakhir inilah yang membawa ideologi selalu dikaitkan dengan Marxis dan berbagai paham kelompok kiri lainnya.

Pada definisi yang kedua ini ditandaskan bahwa ideologi berhubungan kekuasaan dan pembenaran dominasi. Ketika kedua pengertian ideologi tersebut dihubungkan dengan ideologi kultural dalam pemertahanan bambu dapatlah diartikan bahwa upaya masyarakat dalam pemertahanan bambu dilandasi oleh pengetahuanpengetahuan budaya yang telah diwarisinya secara turun temurun sehingga membentuk sistem kepercayaannya. Pengetahuan itulah yang akhirnya berkembang menjadi ideologi yang dimapankan melalui kekuasaan lembaga adat sehingga menjadi sebuah pembenaran dominasi yang dipercayai akan menjadikan masyarakat harmonis dan sejahtera.

\section{Budaya}

Ada beberapa hal empirik yang melandasi dilakukannya mempertahankan bambu yaitu bambu dipandang sebagai warisan turun temurun dan bambu sebagai medium dalam mengasah modal kultural masyarakat. Melalui keberadaan bambu masyarakat diajarkan untuk mengasah dan memelihara pengetahuan leluhur tentang caracara memanfaatkan bambu agar berguna dalam kehidupan di rumah tangga maupun masyarakat. Dalam konteks ini, secara tidak langsung masyarakat dari sejak kecil sudah mengenal bambu dalam kesehariannya. Bangunan rumah dari bambu, alat-alat masak, permainan (misalnya, tajog), alat-alat upacara merupakan kumpulan pengetahuan tradisional yang mengendap dalam memori anak. Pada prinsipnya, bambu telah mengajarkan masyarakat sebuah bentuk kultur yang diperoleh melalui proses pembelajaran yang terus menerus selama hidupnya. Pemakaian bambu untuk keperluan upacara tergolong dominan. Dalam konteks ini terjadi pula proses inkulturasi antar generasi yang berujung pada penanaman pengetahuan mengolah bambu dari satu generasi ke generasi berikutnya.

Untuk kasus tiga daerah yang menjadi locus penelitian ini Living Museum Bambu 3 (tiga) daerah ini, yaitu di Provinsi Jawa Barat, Daerah Istimewa Yogyakarta (DIY), dan Nusa Tenggara Timur (NTT) karena kehidupan nilai spiritual, khususnya nilai kesakralan dan religio-magis, secara tidak langsung Living Museum Bambu tersebut mengkonservasi lingkungannya, karena warga sekitarnya tidak akan berani mengganggunya sehingga lingkungan alam tumbuh dan berkembang 
secara alami. Selain itu, kebutuhan berbagai bahanbahan alami bambu untuk ritual memotivasi warga untuk membudidayakan keanekaragaman vegetasi dan fauna di lahan milik masyarakat. Budidaya dan pertumbuhan lingkungan secara alami sangat bermanfaat untuk pemenuhan kebutuhan ritual dan perolehan bahan untuk konstruksi Living Museum Bambu. Karena nilai guna dan keindahannya, karya budaya (living monument) tersebut terus dipelihara dan dimodifikasi dan didayagunakan oleh generasi berikutnya sesuai dengan kebutuhan dan perkembangan lingkungannya dan selanjutnya diwariskan kepada anak cucunya.

Proses budaya yang demikian disebut warisan budaya. Lebih jelasnya warisan budaya (cultural heritage) dapat diartikan sebagai harta pusaka budaya dari masa lampau yang digunakan untuk kehidupan masyarakat sekarang dan kemudian diwariskan untuk generasi mendatang secara berkesinambungan. Pengertian warisan budaya ini mirip dengan pengertian budaya menurut Young (Kroeber, Al. And Kluckhohn, C, 1952: 55), yaitu keseluruhan hasil budaya dari perilaku belajar atau berpola dari kelompok masyarakat tertentu yang diwarisi dari generasi sebelumnya dan kemudian ditambahkan (dimodifikasi), selanjutnya diwariskan ke generasi berikutnya.

Warisan budaya dapat berwujud tangibel culture (candi, prasada, bangunan pura, masjid, gereja, wihara/klenteng, goa hunian/pertapaan, patung, tekstil, alat musik, dsb), intangible culture (institusi sosial: subak, bajar, desa adat pemaksaan/ pengemong pura; ritual, dsb.) dan abstract culture (sistem nilai, sistem norma, hukum adat, filsafat, ideologi, dsb).

Sementara itu, pengertian lingkungan dapat mecakup makna yang komprehensif maupun secara spesifik. Seperti terungkap dalam UU PLH No 23 Tahun 1997, lingkungan adalah kesatuan ruang dengan semua benda, daya, keadaan dan mahluk hidup termasuk manusia dan perilakunya yang mempengaruhi kelangsungan peri kehidupan serta kesejahteraan manusia serta mahluk hidup lainnya. Pengertian lingkungan ini menyangkut berbagai sumberdaya, yaitu; (1) semberdaya manusia, sumberdaya alam hayati dan non hayati, dan (3) sumberdaya buatan (budaya). Jadi pemahaman lingkungan dalam pengertian ini lebih diartikan sebagai hubungan interdependensi antara lingkungan buatan/lingkungan binaan (monumen) sebagai hasil karya manusia masa lampau (warisan budaya) dengan lingkungan sosio-kultural masyarakat kontemporer dan lingkungan alam yang ada di sekitarnya. Salah satu bentuk warisan budaya dari masa lampau yaitu living monument bamboo.

Berbicara tentang Living Monument Bambu tentu tidak dapat dilepaskan dari konteks warisan budaya (tinggalan Arkeologi) dengan kehidupan lingkungannya, baik lingkungan sosial dengan budayanya yang masih hidup (kontemporer) maupun lingkungan alamnya yang mendukung keberadaan warisan budaya tersebut. Living Monument Bambu dapat diartikan bahwa benda (monumen) tersebut mempunyai hubungan yang sangat erat dengan masyarakat kontemporer selaku pendukung budaya tersebut dan masih difungsikan dalam sistem kehidupan sosio-kultural tertentu.

Hubungan tersebut dapat menyangkut sejarah sosial, seperti konteks sosial religi, sosial ekonomi, politik dan sosial kekerabatan (genealogis), dan konteks kultural. Living Monument Bambu mencerminkan kelekataan hubungan dan dinamika kehidupan sosial dan budaya secara diakronis dari masa-ke masa dengan segala modifikasinya sebagai mekanisme adaptasi terhadap perubahanperubahan yang ditimbulkan, baik dari dalam (internal) maupun faktor perubahan yang berasal dari luar (ekternal), termasuk bidang kehidupan seni (berkesenian).

\section{Simbolisme dalam Bambu}

Bambu dalam dimensi seni membentuk pikiran dan karakter sebagai simbol artefak budaya yang pada gilirannya menciptakan bentuk komunikasi, simbol kecerdasan, emosi dan keyakinan (Scheffler, 1977):

Penerapan secara sadar dari proses materi inilah yang memberi makna pada kehidupan, sehingga kehidupan dan karakteristik prinsip itu dalam kehidupan masyarakat tidak dapat dipisahkan. Fenomena ini menunjukkan bahwa setiap tindakan merupakan reaksi terhadap kesan suatu simbol. 
Simbol tersebut membentuk suatu hari dalam kehidupan penciptaan seni bambu. Secara eksplisit, perilaku menjadi simbol dari dunia nyata dan berhubungan dengan objek, tindakan dan konsep yang terdapat di lingkungannya; sedangkan implisit, karena sifat kedalaman bahwa pikiran membentuk simbol dan tindakan yang memiliki ikatan dengan psikologi dan keyakinan mereka. Manifestasi perilaku (White, 1969) "manifestasi biologis manusia mempengaruhi proses tradisi budaya yang berlaku".

Penggambaran keadaan kemampuan masyarakat untuk menggunakan pengetahuan dan pengalaman mereka dengan penciptaan langsung ekspresi seni bambu. Terbentuknya berbagai ekspresi seni bambu menunjukkan ciri-ciri yang seimbang yang memiliki bentuk yang sama dengan budaya di daerahnya. Bentuk dan proses yang berlaku pada bentuk simbolik tersebut merupakan perwujudan dari pikiran dan karakter.

Bambu adalah simbol yang menjelaskan sesuatu yang berkaitan dengan objek itu sendiri sebagai simbol metaforis, ide dan kreativitas, ekonomi (Rao, Ramanuja, B. Sastry, Cherla, Widjaja, 1996). "Dalam ekspresi metaforis simbolik dapat menciptakan suatu budaya yang menjadi simbol budi pekerti dan watak perbuatan dalam mengendalikan perilaku sendiri, keluarga dan lingkungan masyarakat”.

Ekspresi seni media bambu telah mewarisi bentuk simbolisme pikiran dan karakter yang melekat pada sarana komunikasi. Dua pertanyaan yang muncul ketika mempelajari berpikir dan bertindak adalah cara berkomunikasi terkait aspek internal dan aspek eksternal pikiran yang terkait dengan budaya. Keberadaan dan pemanfaatan seni bambu sebagai lambang budi dan pekerti, menunjukkan kemampuan kreasi menggunakan pengalaman, intuisi dan kesadaran akan pengalaman psikologis dan sosiologis kehidupan mereka.

Persyaratan untuk memenuhi tujuan psikologi pribadi dan nilai-nilai sosial masyarakat, menunjukkan keunikan konsep penciptaan dengan simbol-simbol budaya peradaban masyarakat yang diproduksi dan diterima sebagai sarana kehidupan sehari-hari. Simbol dapat dinilai melalui pandangan objektif, sebagai sesuatu yang memiliki nilai estetis dan melalui pandangan subjektif sebagai sesuatu yang memiliki perasaan. Kedua ciri yang melekat pada kreativitas dan apresiasi orang lain menjadikan seni bambu bermakna sebagai simbol budi pekerti dan karakter sosial budaya di masyarakatnya.

Simbolisme dalam kehidupan mereka merupakan bentuk penekanan atau ekspresi budaya yang merupakan warisan masa lalu. Warisan sejalan dengan pandangan bahwa simbol terbentuk dari pengaruh sejarah dan kehidupan sehari-hari, kepercayaan dan agama serta lingkungan (Turner, 1967), "Masyarakat menganggap simbol-simbol pikiran dan tindakan sebagai tanda kepekaan, barang orisinal, lahir untuk mengingat sesuatu yang istimewa sebagai pemberi makna hidup mereka”. Dengan demikian sifat konteks, pengalaman berperan penting sebagai landasan evaluasi atau interpretasi suatu simbol. Sistem yang kompleks mungkin tidak bermakna di satu sisi dan di sisi lain berarti memiliki signifikansi dalam evaluasi atau interpretasi simbol yang dirujuk.

Dampak sosial budaya dari simbolisme pikiran dan karakter yang membentuk budaya membuat ekspresi seni dari bambu. Simbol dalam bentuk seni dari bambu menggambarkan perilaku atau karakteristik tertentu atau integrasi kekuatan pikiran melalui ekspresi objek bambu sebagai ekspresi alami dan merata yang menggambarkan objek atau ide seni yang dihasilkan.

Budaya konsisten dengan sifat penekanan yang oleh (Langer, 1976) dianggap sebagai keyakinan, penilaian dan interpretasi: "Musik dipahami sebagai keberadaan dalam pemikiran kita”. Bentuk-bentuk seni dari bambu sangat kompleks; ada ilmu pengalaman, kepercayaan, seni, moral, untuk memenuhi kebutuhan ekspresi diri dan juga kehendak masyarakat. Tradisi dan pengalaman terutama anggota keluarga merupakan warisan bagi masyarakat. Pengalaman individu juga memberikan kontribusi terhadap tradisi masyarakat yang menyarankan pemikiran kolektif dan tindakan yang membentuk dan mencirikan pikiran dan karakter simbolik dalam sosiokultural di masyarakat.

Hasil pengalaman telah membentuk suatu sistem dalam pembentukan ilmu-ilmu dalam masyarakat. Proses pembelajaran tidak diterapkan 
secara formal melalui warisan seni dari bambu. Prosesnya membutuhkan waktu yang lama karena melibatkan banyak bidang spesialisasi dalam berlangsungnya kehidupan sosial masyarakat. Sebuah proses yang panjang telah meninggalkan kesan mendalam di benak dan karakter para pencipta seni dari bambu, serta membentuk simbol-simbol yang dapat dimaknai dari berbagai sudut. Dari segi bahan, bambu telah menjadi simbol terbentuknya kesadaran tinggi di alam. Kesadaran tersebut diwujudkan dalam pikiran dan karakter masyarakat melalui pemanfaatan bambu yang tumbuh liar di daerahnya. Kesadaran akan bambu sebagai bahan penting dalam pembuatan seni dari bambu menciptakan nilai budaya dan memberi makna dalam kehidupan mereka. Bambu telah membentuk simbol-simbol yang membentuk ekspresi masyarakat dalam bentuk. Proses penciptaan ini berlanjut dalam membentuk pikiran dan karakter individu yang meliputi emosi, perasaan, sentimen dan harga diri. Jelas ada juga perbedaan dalam penciptaan bentuk seni karena perbedaan individu, namun secara individual terintegrasi dengan kebutuhan di lingkungan masyarakat, terlebih dalam menghasilkan berbagai produk yang menjadi komoditas masyarakat.

\section{Komoditi}

Bambu sebagai Hasil Hutan Bukan Kayu (HHBK) atau sering juga disebut Hasil Hutan Non Kayu (HHNK) merupakan semua benda biologis termasuk jasa lingkungan yang berasal dari hutan atau tegakan hutan, kecuali produk berupa kayu. Definisi lain yang mengartikan HHBK adalah Undang-Undang Nomor 41 Tahun 1999 dan Peraturan Menteri Kehutanan Nomor 35 Tahun 2007.

Hasil hutan bukan kayu terdiri dari bendabenda hayati yang berasal dari flora dan fauna. Selain itu termasuk jugas jasa air, udara, dan manfaat tidak langsung daru hutan (UndangUndang Nomor 41, 1999). Hasil hutan bukan kayu (HHBK) adalah hasil hutan hayati baik nabati maupun hewani beserta produk turunannya dan budidaya kecuali kayu yang berasal dari hutan (Peraturan Menteri Kahutanan No. 35, 2007).
Bambu memiliki potensi besar sebagai komoditas ekonomi yang bernilai budaya dan bermanfaat konservasi. Untuk itu pemerintah terus mendorong industri bambu rakyat di antaranya dengan pembangunan 1.000 desa bambu. Bambu merupakan komoditi strategis, dan Indonesia peringkat ke-3 penghasil bambu di dunia. Upaya yang tidak kalah penting kedepan yaitu bagaimana bambu dikelola dalam skala ekonomi untuk keperluan dalam negeri dan potensial untuk pengganti kayu dan untuk ekspor.

Dengan besarnya potensi bambu di Indonesia, potensi bambu dapat dikembangkan lebih maksimal hingga lebih mampu menjadi produk hasil hutan non kayu, tanaman bambu tidak memerlukan waktu lama hingga siap dipakai. Usia tanam bambu hingga siap panen hanya berkisar selama 4-5 bulan. Jauh lebih cepat dibandingkan komoditas kayu pada umumnya.

Bambu dapat menjadi sektor pendapatan yang mampu meningkatkan perekonomian masyarakat Indonesia. Tanaman bambu dapat dijadikan bahan baku bagi berbagai industri. Semisal bahan baku untuk pembuatan produk Seni. Bambu memiliki nilai tersendiri dalam seni, memiliki nilai jual yang cukup tinggi dan banyak digunakan sebagai bahan dasar komoditas seni di Indonesia. Estetika atau keindahan bambu sebagai komoditas, terlihat ketika bambu tersebut sudah diolah. Struktur bambu yang tidak teratur akan terlihat lebih mencolok ketika penempatan atau penggunaan bambu tersebut dilakukan dengan benar. Bambu memiliki diameter yang berbeda, apabila perbedaan tersebut disatukan membentuk suatu dinamika maka akan memunculkan nilai estetika (keindahan).

Dalam isu pemanasan global saat ini berakibat terhadap peran dan tanggung jawab pencipta produk kebudayaan dalam menciptakan karya budayanya. Di samping isu pemanasan global, dunia juga sedang mengalami krisis kayu. Dalam proses penciptaan karya budaya seringkali pengkarya mengedepankan lifestyle yang memberikan peluang dalam konsumeristik dan kreatifitas dengan mengeksploitasi lingkungan tanpa memikirkan merawat dan melestarikan lingkungan serta alam. Kondisi tersebut saat ini dijawab dengan solusi karya yang mengedepankan 
konsep ramah lingkungan dan berkelanjutan atau lebih dikenal dengan green design (eco friendly).

Konsep tersebut memiliki misi untuk menjaga keseimbangan dan melestarikan alam. Penggunaan material atau bahan dalam karya seni semakin mempertimbangkan efek polutan dan limbah yang dihasilkan dalam proses produksi sehingga efek dari limbah tersebut terhadap lingkungan diharapkan semakin berkurang, bahkan nol sampah. Dalam beberapa tahun terakhir dunia sedang berpaling ke material bambu setelah hutan tropis sebagai penyedia kayu mengalami krisis. Bambu dinilai sebagai bahan yang berkelanjutan. Negara-negara maju telah memberikan perhatian lebih terhadap riset bambu sebagai bahan komoditas.

Karya budaya yang berwawasan ekologis dengan implementasi konsep green design atau eco friendly sebagai penerapan etika lingkungan dalam karya budaya saat sekarang mendesak untuk dilakukan sebagai gerakan bersama. Beberapa kearifan lokal yang digunakan oleh leluhur dalam pemanfaatan lingkungan dengan merawat tanpa mengekploitasi secara banal menjadi bagian yang harus diimplementasikan saat ini. Para leluhur bangsa Indonesia lebih mengutamakan konsep yang ramah lingkungan dalam menghasilkan produk. Kearifan lokal dalam pemanfaatan material bahan menjadi hal penting dalam proses penciptaan karya budaya berkonsep green design/eco friendly. Dalam dunia kebudayaan peran yang saling terkait antara bagian penjualan atau marketing, desain, dan produksi sebagai pelaksana konsep green design/ eco friendly menjadi sangat penting.

Daya saing produk dengan konsep yang bertanggung jawab terhadap kelestarian alam dan desain yang kreatif, unik, detail serta penyelesaian yang sempurna mampu menjadi produk desain karya yang unggul. Bahan baku produk bambu berkonsep green design/eco friendly menjadi hal pokok dalam implementasi konsep karya dan proses produksi agar mendapatkan hasil yang sempurna. Bambu sebagai salah satu solusi material yang sangat ramah lingkungan dan salah satu komoditas yang memiliki prospek cukup menjanjikan.

Bambu menjadi bagian dari sumber daya alam Indonesia yang tersebar di seluruh pelosok Nusantara. Menurut Elizabeth, pakar taksonomi bambu dari Lembaga Ilmu Pengetahuan Indonesia (LIPI) menyatakan bahwa bambu melimpah di seluruh kepulauan di Indonesia, kecuali Kalimantan. Dari sekitar 1500 jenis bambu yang sudah dikenal 147 merupakan jenis bambu asli Indonesia termasuk bambu-bambu yang mempunyai nilai ekonomi tinggi (Widjaja, 2013).

Secara budaya masyarakat mempelajari dan meniru karakter bambu dan menjadikannya simbol seperti rasa hormat kepada leluhur (karena tumbuh pesat dan tingginya bisa sampai dengan melebihi tebing), simbol kebersamaan dan kekuatan komunal dalam masyarakat, sokong menyokong, bagai aur dengan tebing (karena tumbuhnya yang bergerombol dan tidak saling mengganggu) Secara fisik sebagian besar dari 300-an suku etnis di Indonesia mempunyai beragam pusaka dan kreatifitas yang terbuat dari bambu diantaranya suku Sunda, menyanyi dengan angklung atau calung, suku Bali menggantung tingklik bambu di tiang beranda dan suku Payakumbuh meniup Saluang Sirompak yang bersuara merdu memilukan (Ramalis Soebandi dalam diskusi Bamboo Biennale, 7 April 2014). Seperti yang disampaikan para peneliti dan akademisi dari ITB Mustakim dkk. (www.academia.edu, diakses 19 Mei 2014).

Bambu adalah salah satu material yang hampir memenuhi seluruh syarat tersebut untuk sebagian besar wilayah Indonesia. Kekuatan tariknya yang dapat setara dengan baja dan kekuatan tekannya yang dapat setara dengan beton menjadikannya sebagai alternatif terbaik saat ini. Tumbuhan ini juga bermanfaat besar terhadap lingkungan karena dapat menjaga kondisi tanah, air, dan udara lebih baik dibanding tumbuhan lain pada umumnya. Kecepatan bambu untuk tumbuh, dapat memenuhi syarat sebagai material konstruksi hanya dalam beberapa tahun serta memiliki banyak manfaat dan kegunaan lainnya, menjadikan bambu sebagai komoditas alternatif industri padat karya di hulu maupun di hilir. Pada hulu berupa agro-industri penghasil bahan baku berupa rebung, bahan kerajinan, bahan bangunan, dan sebagainya, sedangkan di hilir berupa industri makanan, kerajinan, dan industri konstruksi. 


\section{Bambu di Wilayah Selaawi, Jawa Barat}

Jawa Barat terkenal dengan wilayah penghasil bambu dengan berbagai probematikanya, baik terkait pemanfaatan (alat rumah tangga, kerajinan, maupun alat musik) juga hubungan konteks sosialnya. Hal ini dapat dilihat dari berbagai penelitian yang telah dilakukan, di antaranya (Upaja Budi, Dinda Satya, Soedarsono, RM, Haryono, Timbul, Narawati, 2014); (Upaja Budi, 2017); (Cundaningsih, Nurvita, 2015); (Saepudin, 2017); (Tedjasendjaja \& Dharmadi, 2015); (Susanti, Santi, Sjuchro, 2019); (Heryanto et al., 2017).

Selaawi termasuk salah satu daerah penghasil bambu di Jawa Barat. Nama Selaawi menurut catatan yang ada di pemerintahan daerah desa disebutkan diambil dari nama sebuah kampung yang berada di wilayah Desa Selaawi, Kecamatan Selaawi, Kabupaten Garut. Kata selaawi dalam perspektif etimologi berasal dari dua kata yaitu kata 'sela' dan 'aw'i, karena pada zaman dahulu banyak

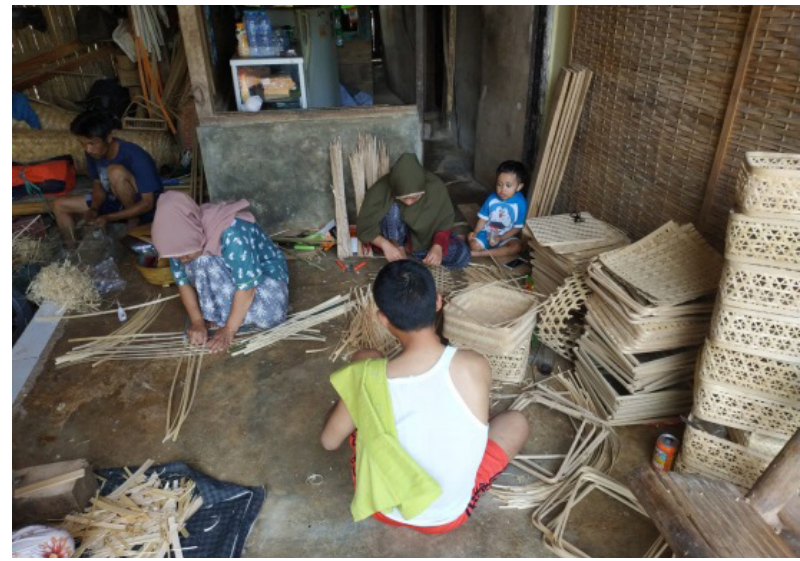

Gambar 1: Proses pengerjaan dan produksi bahan bambu. (Dok: 2021)

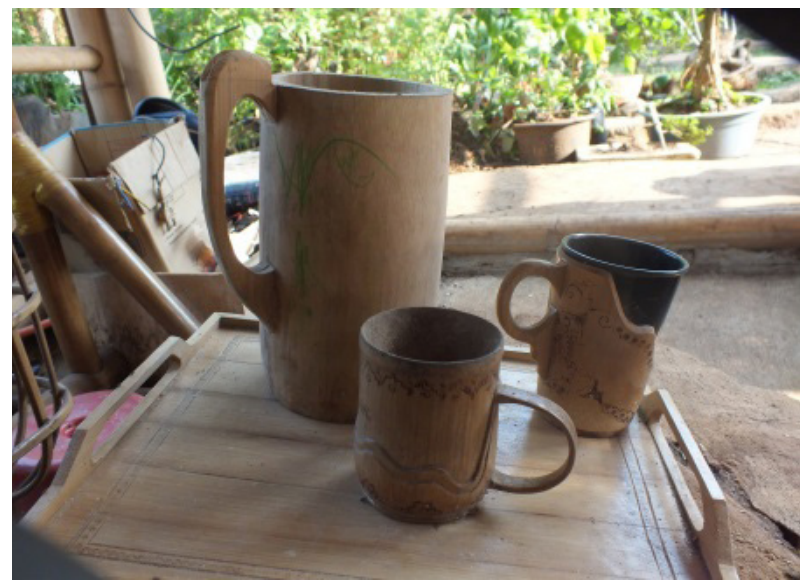

Gambar 2: Cangkir bambu. Beberapa jenis alat minum hasil kerajinan (kriya) bambu. (Dok: 2021) sekali pohon bambu (Sunda; awi) yang menjadi sumber penghidupan bagi masyarakat sekitarnya.

Begitu juga di Selaawi, sejak awal berdirinya wilayah Selaawi (lihat sejarah Selaawi), bambu digunakan untuk keperluan kebutuhan rumah tangga sehari-hari (seperti: bakul/boboko, dingkul, aseupan, hibid, giribig, nyiru, cecempeh, pipiti, dll.), bahan bangunan rumah (bilik, palupuh, dll), kebutuhan lain (bubu, posong, korang, ranggap, sangkar burung, dll.). Para pengrajin melakukan pemasaran hasil produknya baik secara online maupun offline (Susantil et al., 2020).

Seiring perkembangan teknologi dan pergeseran kebutuhan masyarakat, maka pada perkembangan selanjutnya kerajinan masyarakat tersebut mengalami pergeseran untuk kebutuhan barang sekunder atau sebagai barang cindera mata. Gambar 2, Gambar 3, dan Gambar 4 merupakan contoh yang menggambarkan hasil kerajinan masyarakat Selaawi dalam mengolah bambu serta kerajinan yang dapat mereka hasilkan.

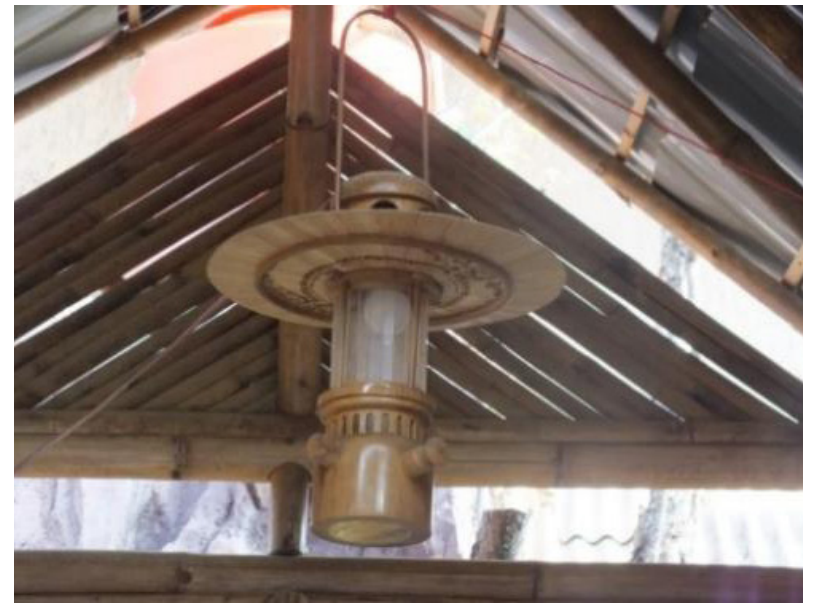

Gambar 3: Lampu petromak. (Dok: 2021)

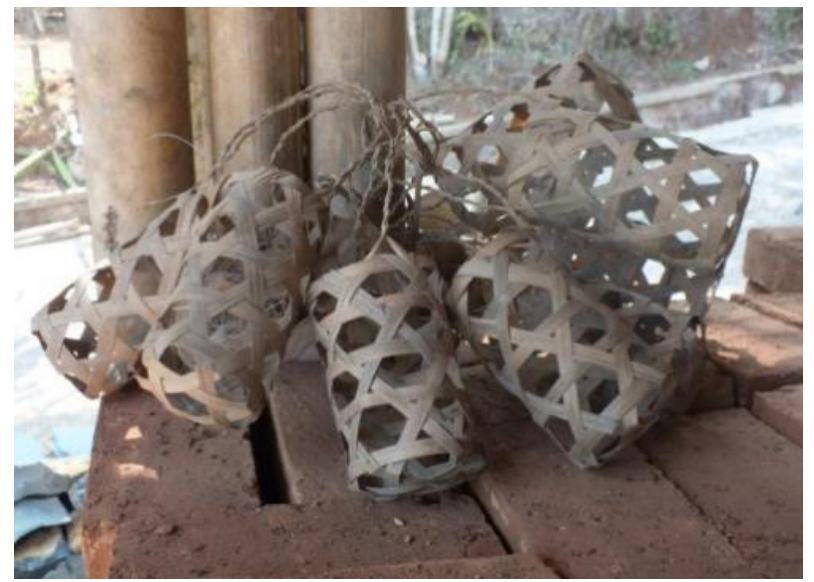

Gambar 4: Bentuk wadah galon. Tempat galon air isi ulang berbagai ukuran. (Dok: 2021) 


\section{Sumber Daya Alam}

Potensi sumber alam berupa bambu di wilayah Selaawi memang cukup banyak, walaupun tak dikatakan melimpah. Daerah gunung dan lembah yang melingkupi wilayah Selaawi hampir dapat dikatakan, semuanya ditumbuhi pohon-pohon bambu yang cukup subur pertumbuhannya. Beberapa jenis bambu yang paling populer di masyarakat Selaawi, antara lain: bambu tali, bambu suratlgombong, bambu betung (bitung), bambu buluh (awi temen), bambu hitam (wulung), bambu bunar, bambu kuning.

\section{Musik Bambu di Yogyakarta}

Pohon bambu termasuk salah satu sumber daya alam yang melimpah terdapat di Yogyakarta.
Pohon bambu tersebar di empat kabupaten yaitu di Kabupaten Bantul, Kabupaten Gunung Kidul, Kabupaten Sleman, dan Kabupaten Kulonprogo (Nadya \& Winarto, 2019). Keempat kabupeten ini memiliki sumber daya bambu yang cukup yang bisa digunakan untuk keperluan warga sekitarnya. Bukan hanya untuk keperluan rumahtangga, sumber bambu ini digunakan pula untuk keperluan kerajinan tangan, membuat mainan anak, membuat alat musik, dan lain-lain.

Di Yogyakarta terdapat musik bambu khas Yogyakarta terdiri dari dua jenis kesenian yaitu Rinding Gumbeng dan Krumpyung. Kedua jenis kesenian ini hidup dan berkembang di tempat yang berbeda, meskipun sama-sama berbahan dasar bambu. Rinding Gumbeng tumbuh dan hidup di Kabupaten Gunung Kidul sedangkan Musik Krumpyung hidup dan berkembang di Kabupaten

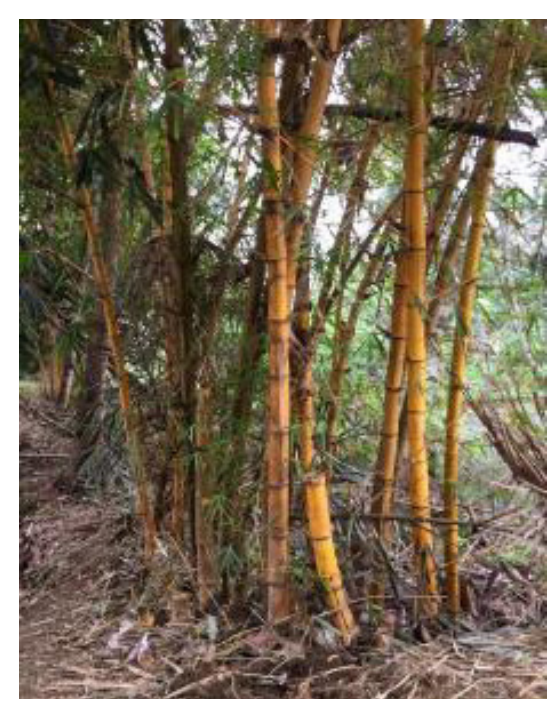

Gambar 5: Haur koneng.

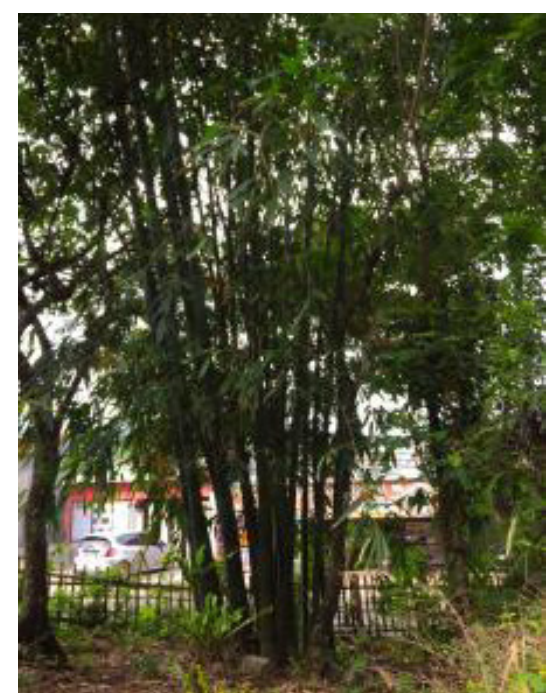

Gambar 8: Awi temen.

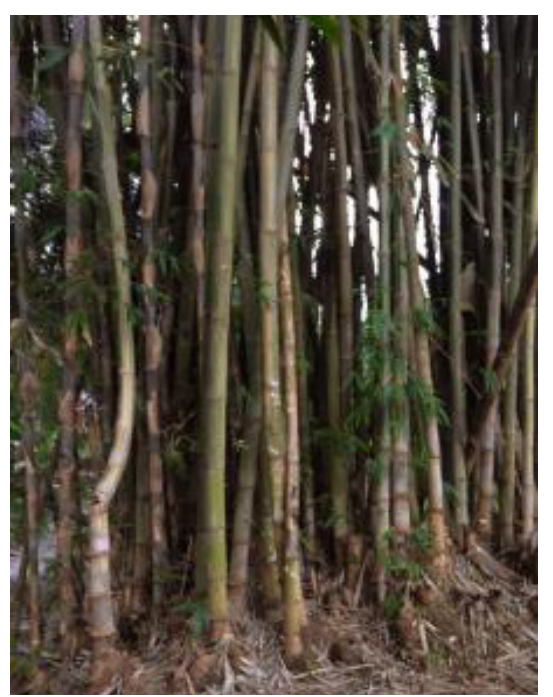

Gambar 6: Awi gombong/awi surat.

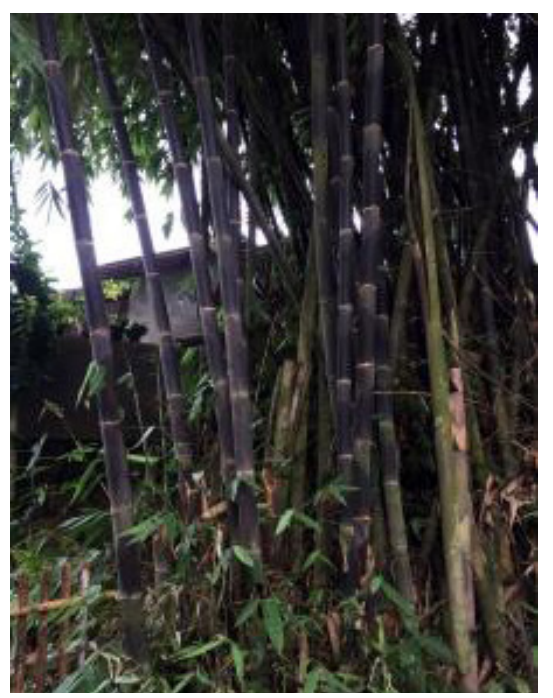

Gambar 9: Awi wulung.

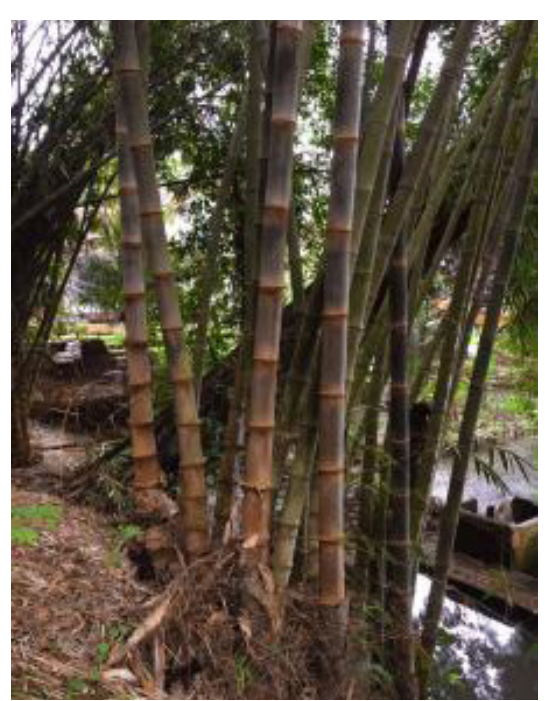

Gambar 7: Awi bitung.

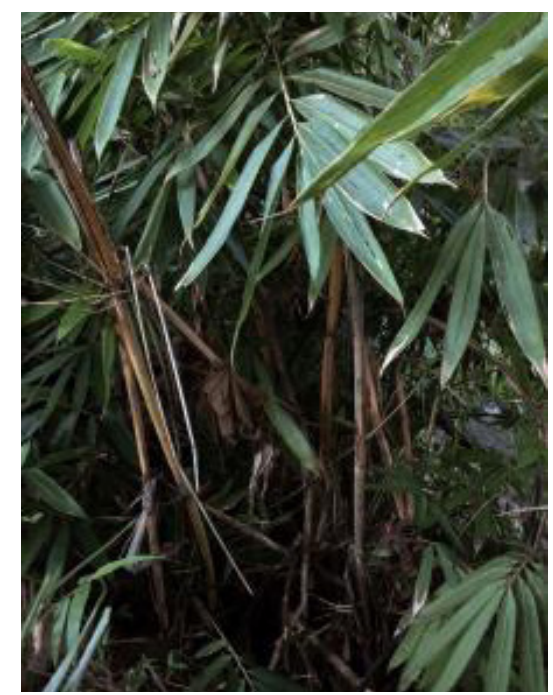

Gambar 10: Awi bunar. 
Kulonprogo. Dua kabupaten inilah yang memiliki potensi musik berbahan bambu di Yogyakarta. Adapun dua kabupaten lainnya yakni Kabupaten Bantul dan Sleman lebih fokus menghasilkan kerajinan tangan dari produk bambunya.

Rinding Gumbeng termasuk salah satu genre kesenian khas Yogyakarta yang berasal dari Kabupaten Gunung Kidul (Ervina Dewi, 2019). Genre ini pada awalnya berasal dari alat musik yang bentuknya kecil yaitu rinding yang terbuat dari bambu. Untuk menambah dalam garapnya, maka rinding digabung dengan musik gumbeng (yaitu salah satu alat musik berbahan bambu yang beberapa bagian diberi lubang) sehingga namanya jadi Rinding Gumbeng. Instrumen lengkapnya terdiri dari rinding, gumbeng, gong, kendhang, kecrek dan angklung. Sering juga Rinding Gumbeng disajikan bersama dengan alatalat modern di dalam pertunjukannya. Rinding Gumbeng masih dimainkan oleh masyarakat di Dusun Duren Desa Beji Kecamatan Ngawen Gunung Kidul.

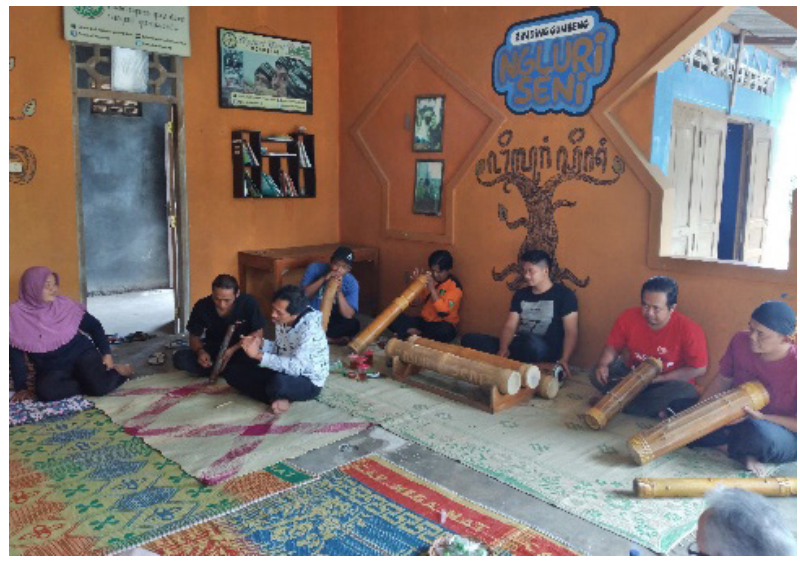

Gambar 11: Rinding gumbeng. (Dok: 2021)

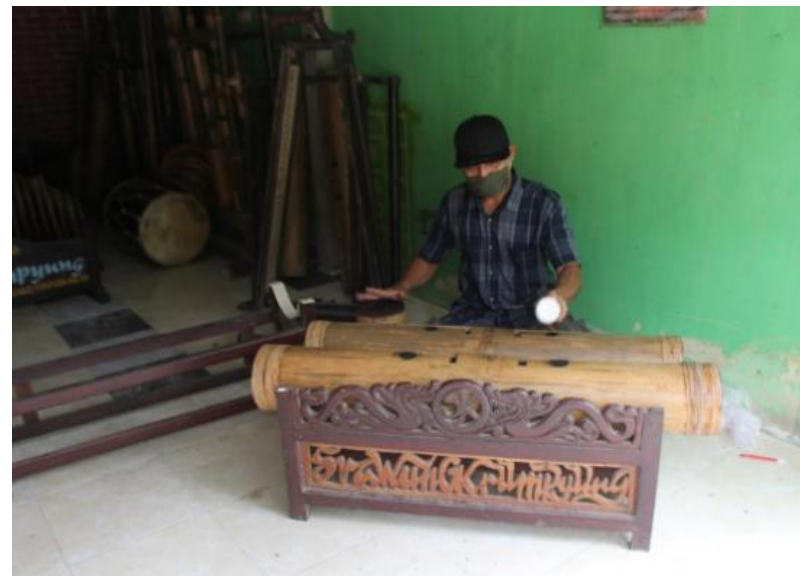

Gambar 12: Kendang bambu dalam musik Krumpyung.
Satu lagi adalah Musik Krumpyung. Musik Krumpyung adalah musik khas Yogyakarta yang berasal dari Kabupaten Kulonprogo.

Musik ini tepatnya berada di Desa Hargowilis, Kecamatan Kokap, Kabupaten Kulon Progo, Yogyakarta. Menurut Sujarwanto, Krumpyung pertama kali diciptakan oleh Sumitra, warga Dusun Tegiri, Kokap, Kulonprogo. Hal ini berawal dari permintaan anaknya untuk dibutakan gamelan. Lalu Ia membuatnya tidak dari bahan perunggu karena mahal, tetapi memanfaatkan bahan bambu yang ada di sekitar tempat tinggalnya. Setelah jadi dinamakan Krumpyung, nama ini berasal dari bunyi alatnya ketika dimainkan berbunyi "krumpyung......krumpyung".

Musik Krumpyung menjadi andalan serta identitas Kecamatan Kokap yang sering dipentaskan di berbagai acara seperti hajatan, upacara adat atau event-event khusus seperti Festival Kesenian Yogyakarta, Festival Manoreh, dan lain-lain. Grup Srawung Krumpyung termasuk salah satu grup musik Krumpyung di Kokap ini. Melalui grup ini dikembangkan berbagai kreativitas garap maupun penciptaan instrumen baru untuk kebutuhan rasa musikal.

\section{Bambu di Flores Timur}

Gambaran kehidupan sosial budaya masyarakat Plores Timur diawali dengan mengamati satu bentuk kesenian tradisi yaitu 'Ruren' di Suku Kau Ama Maran, Desa Ratu Lodong Kecamatan Tanjung Bunga, yang masih berfungsi sebagai media upacara ritual desa, penjemputan Tamu undangan

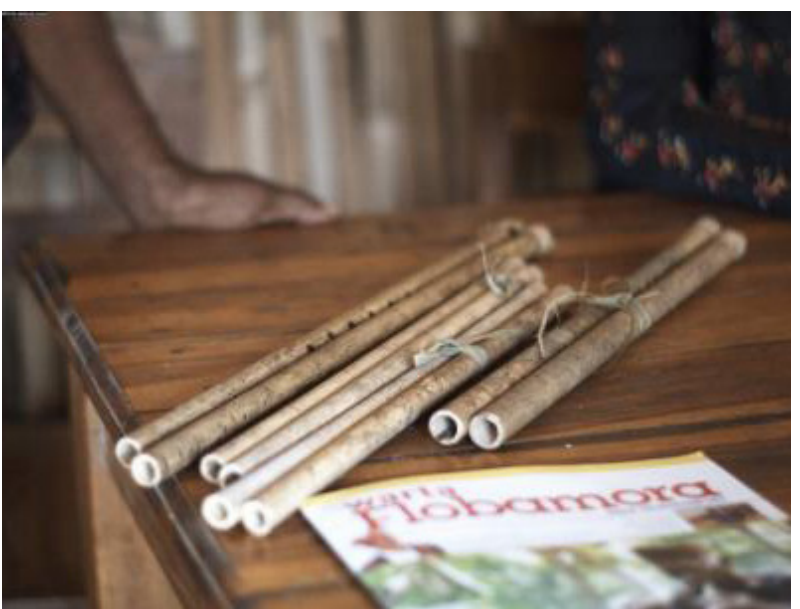

Gambar 13: Instrumen luren, seni luren. (Dok: 2021) 
terutama yang terkait dengan pelaksanaan membangun rumah adat.

Seni ritual Ruren membawa ke dalam pemahaman kehidupan sosial budaya lama masyarakat Larantuka (Froles Timur), yang begitu menjunjung tinggi aturan atau hukum adat yang berlaku. Olehsebab itu, setiap anggota masyarakat melaksanakan seluruh ketetapan adat itu dengan segenap jiwa dan raga sehingga menempatkan aturan adat itu sebagai keyakinan yang utuh., dimana substansinya seluruh alam, lingkungan, dan makhluk yang hidup di dalamnya adalah saudara. Ikatan persaudaraan inilah yang mengikat masyarakat untuk memperlakukan seluruh hidup dan kehidupannya dalam ketetapan hukun adat (religius tradisional; agama adat). Bahkan, hewan yang terkecil sekalipun mendapat tempat dan bagiannya sendiri-sendiri. Hal ini tercermin dari pernyataan isu dalam masyarakat, bahwa "suara ruren itu adalah merupakan pengejawantahan dari suara cacing".

Selain itu, terdapat hal menarik lainnya yaitu seni Seruren. Seni Seruren ini sangat menarik karena adanya indikasi keterkaitan dengan seni ritual Ruren, dan sejarah misionaris Portugis dalam menyebarluaskan agama Katolik. Di sisi lainnya, yang juga menarik adalah para pemain nya tidak hanya kaum laki-laki dewasa saja, tetapi juga ada kaum perempuan ibu-ibu, dewasa, dan bahkan anak-anak.

Dengan kata lain, kita dapat gambaran perkembangan fungsi dan pergeseran nilai (peran) bambu dari seni ritual Ruren ke seni Sururen (Suling) yang difungsikan sebagai media misionaris Katolik kolonial di wilayah pribumi yang berdampak terbentuknya komunitas masyarakat pemelihara dan pengembang seni Suling. Oleh sebab itu, merujuk pada kedua sumber utama tersebut; seni Ruren dan seni Suling, maka selanjutnya adalah menjadikan keduanya sebagai inspirasi pembuatan musik bambu Wiragawi.

\section{Komodifikasi}

Komodifikasi budaya adalah suatu tindakan yang menjadikan unsur-unsur budaya (bahasa, sistem pengetahuan, organisasi sosial, religi dan kesenian) menjadi suatu hal yang bernilai ekonomi dan dapat diperjualbelikan sehingga menimbulkan suatu modifikasi pada unsur budaya tersebut. Di era globalisasi komodifikasi sudah masuk dalam segala lini kehidupan masyarakat, termasuk dalam budaya. Komodifikasi sebagai salah satu ciri era posmodern menjadikan hampir seluruh sisi kehidupan sebagai komoditas untuk diperjualbelikan. Komoditas yang pada mulanya terbatas pada tenaga kerja, tanah, dan uang, kemudian merambah ke segala hal seperti organ tubuh, rasa aman, kebahagiaan, dan lambang keagamaan (Mulyanto, 2012). Bahkan, (Piliang, 2005) menyebutkan bahwa "komodifikasi meluas kepada bidang pendidikan, kebudayaan, hasrat, keagamaan, tubuh, kematian, bahkan ke bidang politik".

Komodifikasi mereduksi makna kehidupan menjadi sekadar makna ekonomi dan pertukaran. Namun, (Barker, 2004) memandang bahwa komodifikasi adalah proses yang diasosiasikan dengan kapitalis, artinya objek, tanda, dan kualitas berubah menjadi komoditas. Komodifikasi yang kami lakukan dalam bentuk seni pertunjukan akan menghasilkan dua model ini, yaitu; berupa galeri pertunjukan karya-karya masyarakat setempat dan berupa karya oratorium dengan media bambu berbasis alam, seni, dan budaya yang dipertontonkan kepada masyarakat luas.

Dalam konteks seni pertunjukan dan membangun ruang hidup material, komodifikasi ini dalam bahasa ibunya adalah kearifan lokal dengan senantiasa menggunakan material lokal dan memuliakannya dengan cara menjaga keberlangsungan kehidupan dan pemanfaatannya. Sebagaimana bambu yang tidak boleh dimarjinalkan dan dilupakan hingga menjadi tanaman yang sulit ditemukan; tidak ditemukan lagi pegunanaannya dalam kehidupan manusia dan tergeser oleh material buatan yang tidak ramah lingkungan.

Berdasarkan kapasitasnya sebagai benda warisan budaya, bambu yang dikonstruksi menjadi media seni pertunjukan sebagai komoditas daya tarik wisata, komodifikasi meliputi tiga aspek, yaitu produksi, distribusi, dan konsumsi. Sebagai bagian dari komodifikasi, ketiga aspek dimaksud memiliki hubungan timbal balik dan saling mempengaruhi satu dengan yang lainnya. Seperti diketahui bahwa 
produk-produk budaya yang dijadikan komoditas juga beragam, tentu dalam mengonstruksinya sebagai benda-benda produksi adalah berbeda.

Komodifikasi Bambu dalam bentuk seni pertunjukan adalah sebuah upaya yang tidak hanya menyajikan produk secara kuantitas, tetapi juga mengedepankan kualitas. Artinya, bahwa komodifikasi bambu ini adalah sebuah bentuk bisnis, tentunya tidak sama dengan pekerjaan memproduksi atau menjual. Bisnis adalah kegiatan yang bersistem dan berorientasi profit dan kepuasan stakeholder. Bisnis merupakan pekerjaan yang bisa ditiru, dikembangkan, didelegasikan, dilimpahkan, dan dijual kepada pihak lain sehingga bisnis bisa berjalan tanpa pemiliknya (Moelyono, 2010).

Pengetahuan-pengetahuan di dalam mengemas dan mengelola warisan budaya sehingga menjadi suatu komoditas yang memiliki daya tarik bagi siapapun yang membutuhkan dan/atau menikmatinya. Untuk mewujudkannya diperlukan inovasi-inovasi cerdas dan mampu mengelola arus dinamika perubahan serta menghargai peranan modal intelektual. Modal intelektual yang dimaksudkan tidak selalu ditentukan oleh tingkat pendidikan formal tinggi, tetapi ditentukan oleh "kekayaan ide yang cemerlang dan mampu menghasilkan kreasi dan inovasi yang berkualitas" (Moelyono, 2010). Ide cemerlang dan kaya inovasi berkualitas sangat dibutuhkan dalam pengelolaan objek atau daya tarik wisata mengingat begitu banyaknya objek wisata menarik sehingga daya saing menjadi lebih tinggi

Komodifikasi bambu memiliki keunikan tersendiri dengan dukungan mitosnya. Hal itu penting mengingat pariwisata yang berbasis budaya dengan mengangkat nilai-nilai kearifan lokal, "unsur-unsur budaya asli yang melekat pada masyarakat lokal serta belum tersentuh budaya luar". Menurut (Boissevain, 1996), "keberadaan seperti itu merupakan salah satu ciri pariwisata budaya" (Pitana, I Gede dan Gayatri, 2005).

Merujuk pada narasi yang cukup panjang tersebut di atas, permasalahan kondisi alam, budaya, seni, komoditas, dan komodifikasi berbagai produk yang dihasilkan masyarakat Indonesia, setidaknya dapat dilihat dalam tiga wilayah potensial bambu, meliputi: (1). Wilayah kehidupan masyarakat
Selaawi, Jawa Barat; (2). Wilayah kehidupan masyarakat Kabupaten Sleman, Kabupaten Bantul, Kabupaten Kulon Progo, dan Kabupaten Gunung Kidul, DIY; dan (3). Wilayah kehidupan masyarakat Wilayah Bantala, Kec. Lewolema, Kab. Flores Timur.

\section{Musik Bambu Wiragawi sebagai Representasi Komodifikasi Bambu Tiga Locus}

Musik bambu secara sederhana dapat dikatakan merupakan hasil kreativitas seniman yang mempergunakan bambu sebagai media yang menghasilkan untaian nada-nada yang terangkai menjadi sebuah karya seni dengan fokus garap pada musikalitasnya. Tulisan ini mendeskripsikan hasil kreativitas musik bambu yang secara khusus diproses di wilayah Selaawi Garut Jawa Barat dengan diberi nama Wiragawi. Kata wiragawi yang diposisikan dalam judul perancangan ini, dalam pendekatan etimologis merupakan gabungan dari dua buah kata (istilah) yaitu kata 'wiraga' dan 'awi. Wiraga [awi], wujud fisiknya bambu dan tidak dimanipulasi menjadi seperti wujud fisik benda (bentuk) yang lain. Terkait dengan hal penjelasan tersebut, di dalamnya mengandung nilai filosofis bahwa manusia tidak boleh melawan kodrat wujud fisiknya. Adapun kata awi itu sendiri merupakan ragam gaya dan wirahma, yaitu ensambel atau instrumen bambu yang dapat digunakan untuk beragam keperluan musikal. Oleh sebab itu, didalamnya mengandung nilai filosofis bahwa "jadi manusa kudu loba pangabisa, sanajan teu mungkin sagala bisa" (manusia itu harus memiliki banyak kemampuan, walaupun tidak mungkin tahu segala hal).

\section{Proses Eksplorasi Musik Wiragawi}

Proses eksplorasi musik bambu Wiragawai, diambil dari tiga metode pisau bedah, dengan sudut pandang sosialisme, simbolisme, dan organologi. Sebagai bahan rujukan berdasarkan fungsi dan kegunaan, dimana bentuk bambu menjadi bentuk sarana masyarakat, simbol keterkaitan sejarah, maupun pemutahiran secara dari fungsi, menjadi unsur baru/fleksibilitas. 
Proses eksplorasi dilakukan langsung di lapangan dengan pendekatan locus-locus yang sudah ditentukan, di antaranya, Jawa Barat, Jawa Tengah, dan Nusa Tenggara Timur. Yang dimana terpusat terhadap eksistensi bambu dalam ranah seni pertunjukan, baik yang masih bersifat kalangenan, maupun yang sudah digolongkan menjadi sebuah instrumen. Instrumen musik bambu dibentuk menjadi sebuah ensemble tentunya dengan menggunakan teori musik barat serta karawitan Sunda. Sehingga bisa dikatakan musik bambu, karawitan bambu, maupun karya seni berlandaskan bambu.

Adapun bentuk-bentuk bambu yang tergolong ke dalam kalangenan dan unsur musik bambu dari ketiga locus tersebut diantaranya:

1. Kesenian Bundengan dari Jawa Tengah. Bundengan merupakan adaptasi dari kowangan yang dalam bahasa Jawa, sebagai alat untuk bantu untuk meneduh dalam mengembala bebek di sawah, berjalannya waktu di rekomposisi menggunakan senar, sehingga menjadi suatu alat musik yang bernama bundengan, dengan karakter mendengung yang dihasilkan dari resonator kowangan tersebut. Team peneliti mengeksplorasi dari sistem organologi. Dari bentuk, cuning, dan fungsi (memodifikasi) menjadi sebuah alat musik string, dengan tujuan komoditas. Adapun skema terdapat pada Gambar 14.

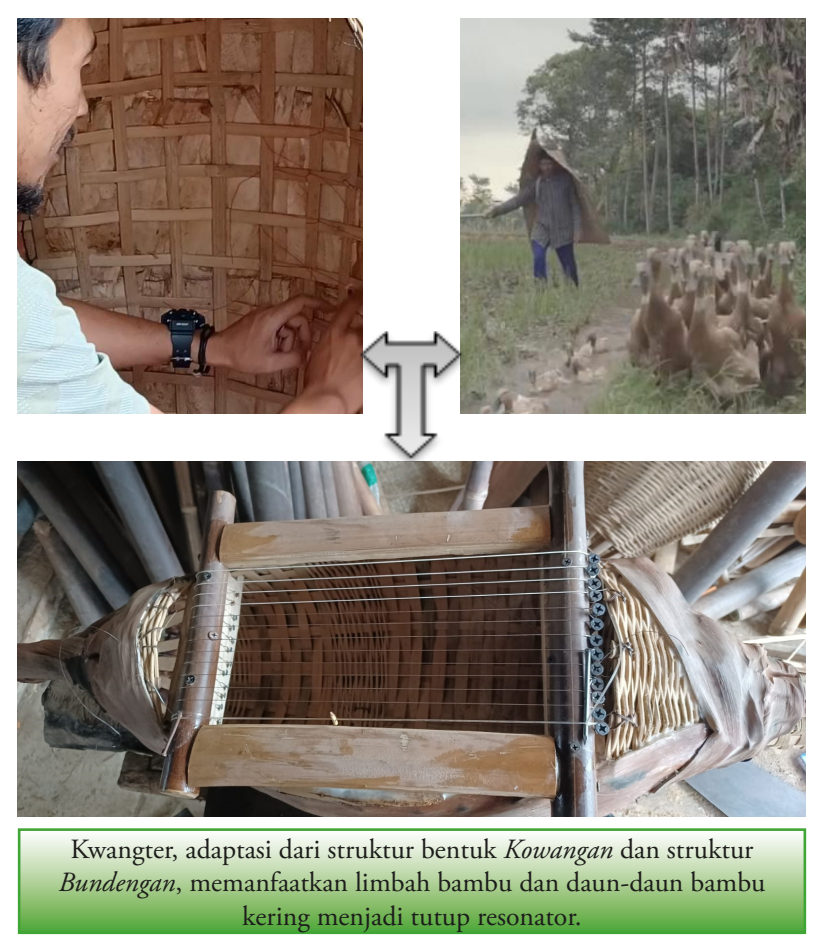

Gambar 14: Kwangter. (Dok: 2021)
2. Marque Melodi. Merupakan adaptasi dari instrumen idiophone, saron (gamelan) yang dimana team peneliti mengeksplorasi bahan-bahan dari bambu, dibentuk menjadi bilah dan bentuk resonator dari suatu bambu menjadi unsurunsur dalam instrumen, seperti, ruang resonator, bilah berdada. Adapun gambar dan skesta dalam bentuk marque seperti pada Gambar 15 . Marque mempunyai panjang keseluruhan 103 $\mathrm{cm}$, dan meiliki lebar $45 \mathrm{~cm}$. Tabel 1 merupakan susunan nada yang terdiri dari sistematis tangga nada Pentatonis, dimulai dari tangga nada 3 (na) tinggi sampai dengan $3(\mathrm{Na})$.

3. Marque Accompagnemen (Gambar 17).

4. Marque Bass. Berkarakter nada rendah, yang diadopsi dari struktur sajian sexholphone dari Flores, Solor, yang berkarakter aerophone menjadi idhiophone adapun gambar dan susunan nada terdapat pada Gambar 18 dan Tabel 2.
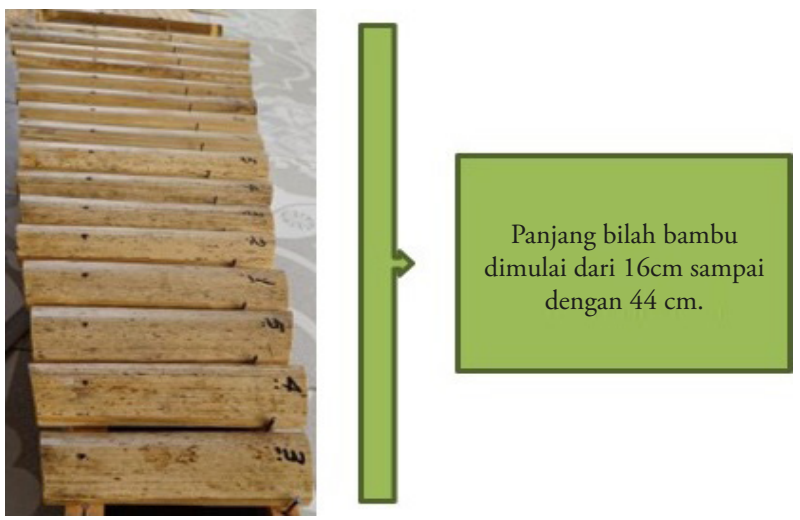

Gambar 15: Panjang bilah bambu. (Dok: 2021)

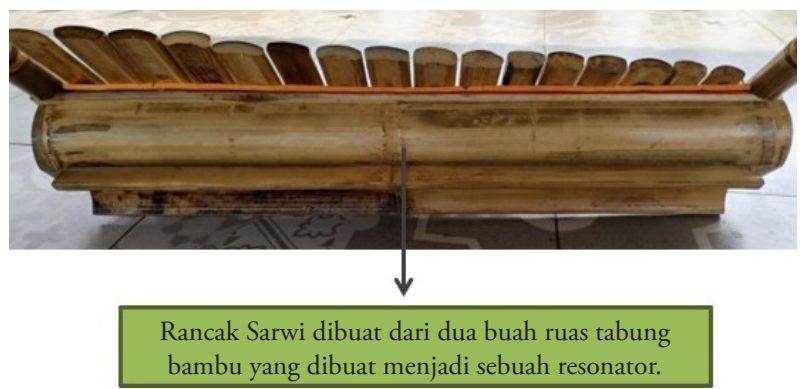

Gambar 16: Rancak Sarwi. (Dok: 2021)

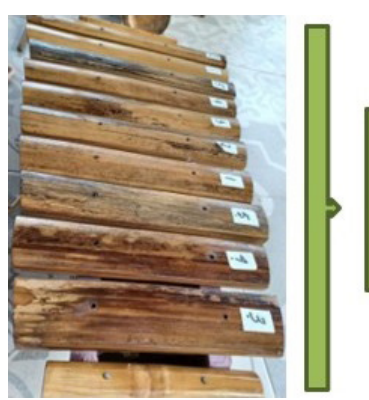

Sarwi pendek terdiri dari 10 bilah bambu, dengan panjang $66 \mathrm{~cm}$ dan lebar $40 \mathrm{~cm}$.

Gambar 17: Sarwi pendek. (Dok: 2021) 
5. Wiron, terbentuk dari ruas bambu, dan terdiri dari sembilan bambu yang dibangun dari satu ruas bambu sebagai resonator, di atasnya terdapat wilah bambu. Ada kesamaan dengan locuslocus di tataran Jawa Tengah, dalam bentuk resonator berupa kohkol, yang dimana kohkol dalam masyarakat Jawa Tengah dipakai dalam sarana sosial, menjaga keamanan kampung, dengan simbol bunyi yang telah disepakati, adapun gambar kohkol daerah Jawa Tengah terdapat pada Gambar 19. Perkembangan dari locus Jawa Tengah dengan hasil komodifikasi menjadi wiron merupakan unsur keberagaman dalam khazanah perkembangan instrumen musik bambu. Wiron dibentuk dengan nada pentatonis seperti yang tertera pada Tabel 3.
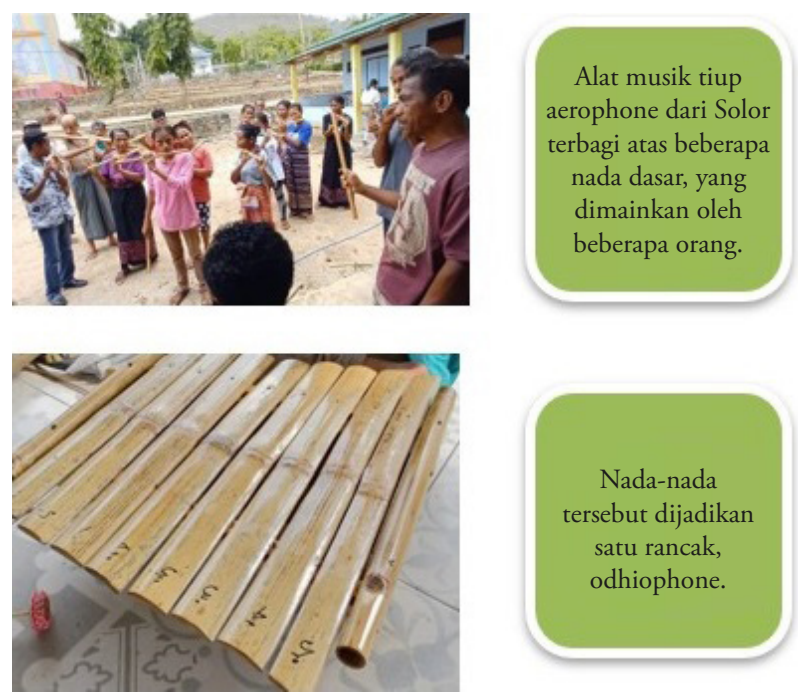

Gambar 18: Odhiophone. (Dok: 2021)

Tabel 1: Urutan tangga nada Marque.

\begin{tabular}{ccc}
\hline Nada) & Pentatonis & Diatonis \\
\hline 1 & $\mathrm{Da}$ & $\mathrm{A} \# 5$ \\
2 & $\mathrm{Mi}$ & $\mathrm{A} 3$ \\
3 & $\mathrm{Na}$ & $\mathrm{F} 5$ \\
4 & $\mathrm{Ti}$ & $\mathrm{D} \# 5$ \\
5 & $\mathrm{La}$ & $\mathrm{D} 5$ \\
\hline
\end{tabular}

Tabel 2: Urutan tangga nada Marque Bass.

\begin{tabular}{ccc}
\hline Nada & Pentatonis & Diatonis \\
\hline 5 & $\mathrm{La}$ & $\mathrm{D} 4$ \\
$5+$ & $\mathrm{Leu}$ & $\mathrm{C} 4$ \\
1 & $\mathrm{Da}$ & $\mathrm{A} \# 3$ \\
2 & $\mathrm{Mi}$ & $\mathrm{A} 3$ \\
$3-$ & $\mathrm{Ni}$ & $\mathrm{G} 33$ \\
3 & $\mathrm{Na}$ & $\mathrm{F} 3$ \\
4 & $\mathrm{Ti}$ & $\mathrm{D} \# 3$ \\
5 & $\mathrm{La}$ & $\mathrm{D} 33$ \\
\hline
\end{tabular}
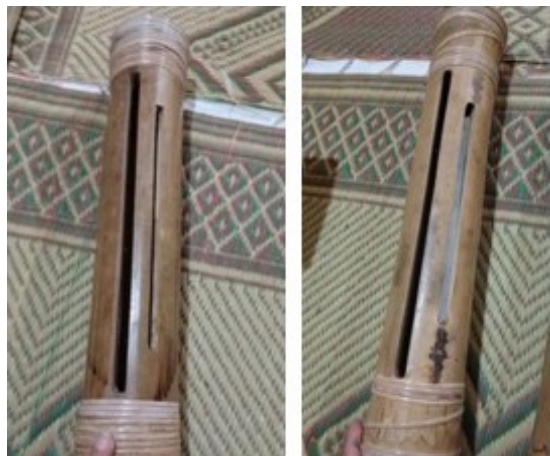

Gambar 19: Kohkol. (Dok: 2021)

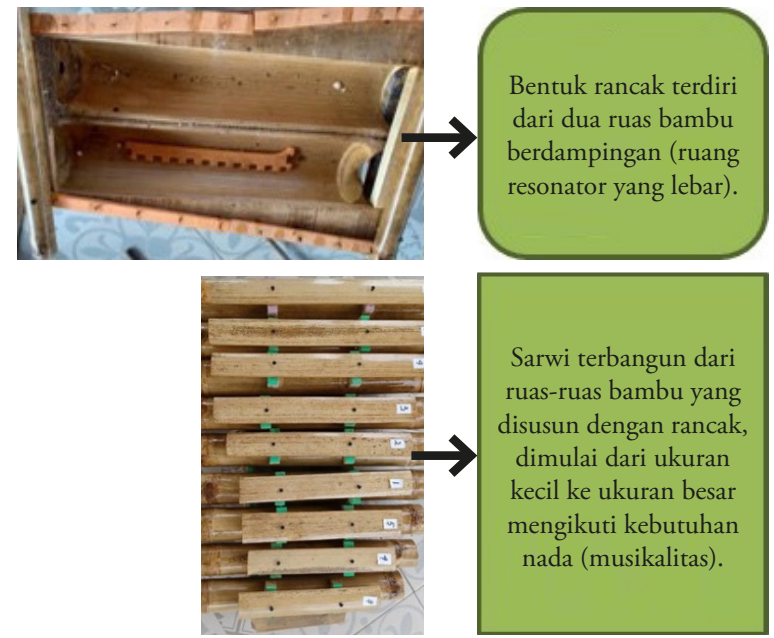

Gambar 20: Sarwi. (Dok: 2021)

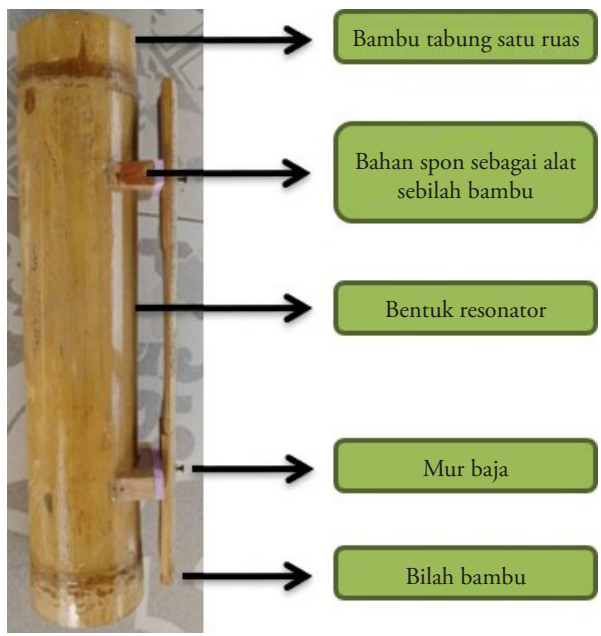

Gambar 21: Wiron. (Dok: 2021)

Tabel 3: Urutan tangga nada Wiron.

\begin{tabular}{cccc}
\hline Nada & Pentatonis & Diatonis & Panjang \\
\hline 3 & $\mathrm{Na}$ & $\mathrm{F} 5$ & $25 \mathrm{~cm}$ \\
4 & $\mathrm{Ti}$ & $\mathrm{D} \#$ & $27 \mathrm{~cm}$ \\
5 & $\mathrm{La}$ & $\mathrm{D} 5$ & $28 \mathrm{~cm}$ \\
1 & $\mathrm{Da}$ & $\mathrm{A \# 5}$ & $30 \mathrm{~cm}$ \\
2 & $\mathrm{Mi}$ & $\mathrm{A} 3$ & $31 \mathrm{~cm}$ \\
3 & $\mathrm{Na}$ & $\mathrm{F} 5$ & $32 \mathrm{~cm}$ \\
4 & $\mathrm{Ti}$ & $\mathrm{D} \# 5$ & $33 \mathrm{~cm}$ \\
5 & $\mathrm{La}$ & $\mathrm{D} 5$ & $34 \mathrm{~cm}$ \\
1 & $\mathrm{Da}$ & $\mathrm{A} \# 5$ & $35 \mathrm{~cm}$ \\
\hline
\end{tabular}


6. Tumras, terbentuk dari tabung sebagai resonator sekaligus alat untuk menabuh dengan panjang tabuh dimulai dari $23 \mathrm{~cm}$ sampai dengan 30 $\mathrm{cm}$ dimana tabung tersebut dibagi dua, sebagai bentuk tabung resonator dan sebagai alas bunyi.

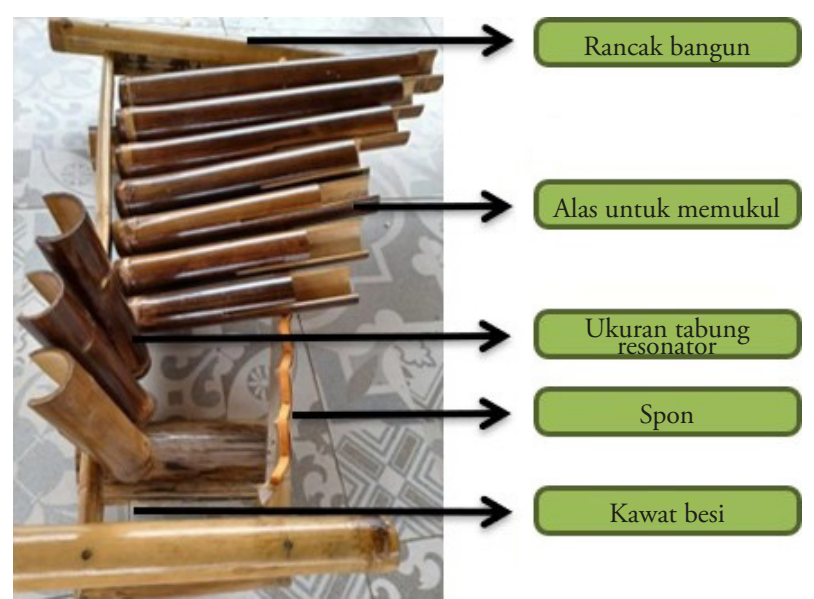

Gambar 22: Tumras. (Dok: 2021)

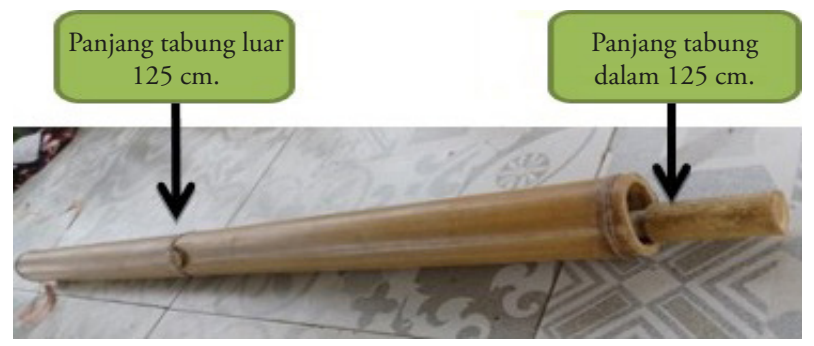

Gambar 23: Goong tiup. (Dok: 2021)

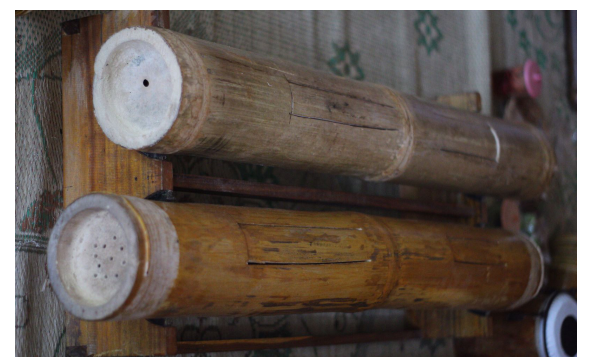

Gambar 24: Gendang grup Rinding, dua batang tabung bambu dengan dua ruas diberi dasaran tengah, mengejar dan menyerupai suara gendang Jawa Tengah (Ciblon). (Dok. 2021)

Tabel 4: Urutan tangga nada Tumras.

\begin{tabular}{ccc}
\hline Nada & Pentatonis & Diatonis \\
\hline 2 & $\mathrm{Mi}$ & $\mathrm{G} \# 5$ \\
3 & $\mathrm{Na}$ & $\mathrm{F} 5$ \\
4 & $\mathrm{Ti}$ & $\mathrm{D} \# 5$ \\
5 & $\mathrm{La}$ & $\mathrm{C \# 5}$ \\
1 & $\mathrm{Da}$ & $\mathrm{A \# 4}$ \\
2 & $\mathrm{Mi}$ & $\mathrm{G} \# 4$ \\
3 & $\mathrm{Na}$ & $\mathrm{F} 4$ \\
4 & $\mathrm{Ti}$ & $\mathrm{D} 4$ \\
5 & $\mathrm{La}$ & $\mathrm{C \# 4}$ \\
1 & $\mathrm{Da}$ & $\mathrm{A \# 3}$ \\
\hline
\end{tabular}

7. Goong tiup, goong suwuk bambu, dibangun dengan dua ruas bambu, sebagai bentuk resonator serta sebagai bentuk bunyi, aerophone.

8. Nama instrumen atau alat musik tiap daerah memiliki kesamaan, gendang dalam bahasa Jawa Tengah dan kendang dalam bahasa Sunda Jawa Barat. Namun dalam konteks bambu Jawa Tengah, gendang juga dipakai dalam instrumen bambu dengan beberapa ruas yang diberikan ruang pukul, sehingga mengeluarkan bunyi menyerupai suara gendang.

9. Notot, dalam bahasa sela awi, merupakan alat bantu untuk berburu yang menyerupai bentuk suling. Berbunyi seperti suara burung yang

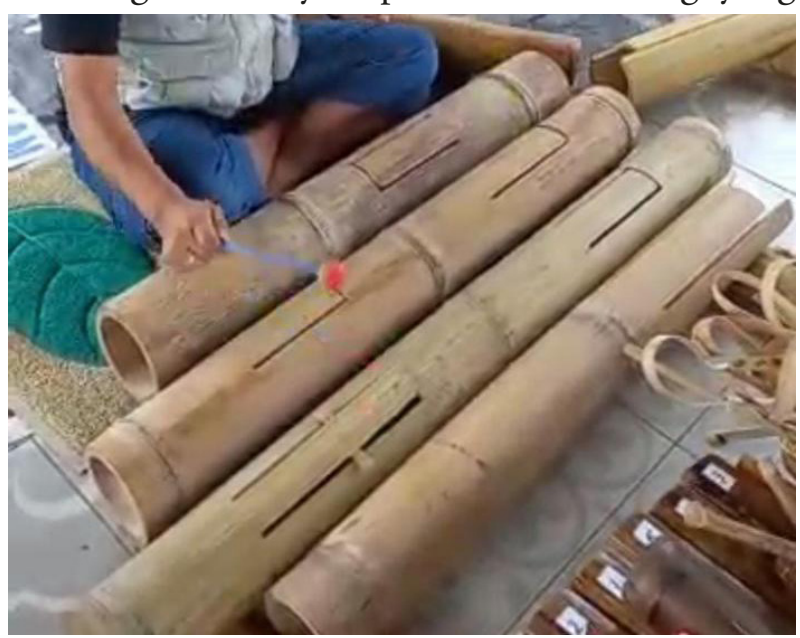

Gambar 25: Kendang dalam Ensemble Wiragawi. Dibuat dari beberapa ruas bambu, yang diberi lubang ditengahnya menyerupai suara kendang Sunda Jawa Barat. (Dok. 2021)

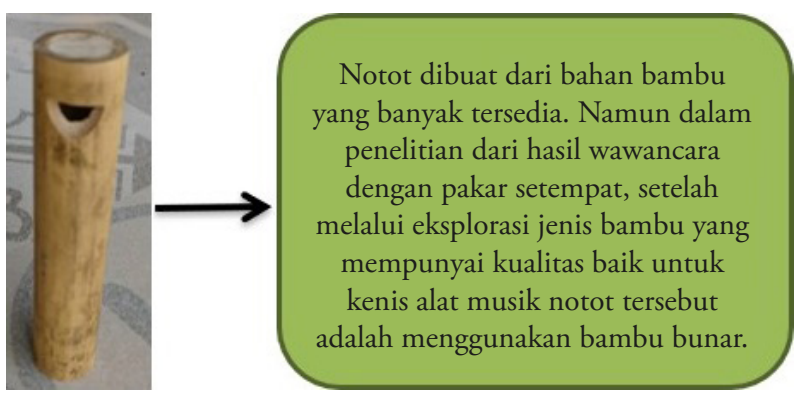
Gambar 26: Notot. (Dok: 2021)

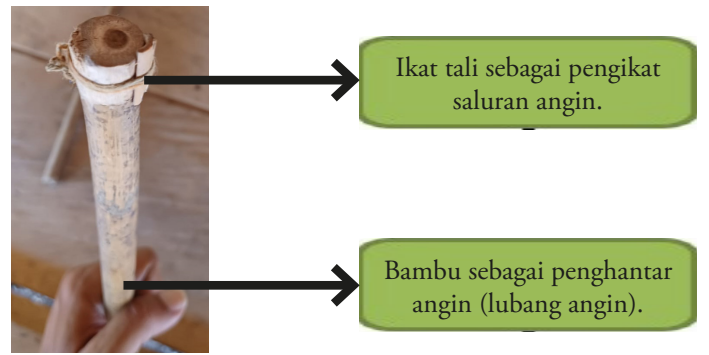

Gambar 27: Bentuk depan instrumen loren. (Dok: 2021) 
masih belajar berkicau. Dalam locus NTT terdapat bentuk seruling luren yang dimainkan secara bersama-sama namun ranah organologi, luren menggunakan teknik ikat dan bentuk aluran bambu, menghantarkan angin.

10. Eksplorasi pembentukan instrumen bambu, dengan beberapa metode, baik didalam pe-

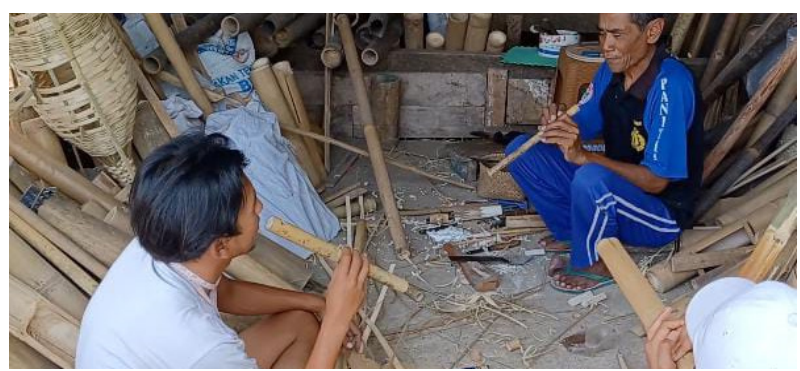

Gambar 28: Proses penyempurnaan alat tiup aerophone, dari NTT Luren dan alat tiup Notot Selaawi. rangkaian dan pelarasan, terhadap musik bambu tersebut. Adapun visual berupa foto di antaranya terdapat pada Gambar 29.

\section{Eksplorasi Karakter Bunyi}

Eksplorasi pembentukan karakter bunyi, bersama para pemuda-pemudi masyarakat Sela Awi, Garut, Jawa Barat. Proses eksplorasi, dimulai dari proses pendalaman teks naskah, teknik tabuh, dan manuskrip-manuskrip syair tembang yeng terdapat di tataan priangan Jawa Barat khususnya mayarakat Selaawi, seperti di antaranya Cigawiran, Ciawian, serta lantunan-lantunan, kearipan lokal berupa kalangenan. Adapun bentuk dokumentasi eksplorasi di antaranya terdapat pada Gambar 30.
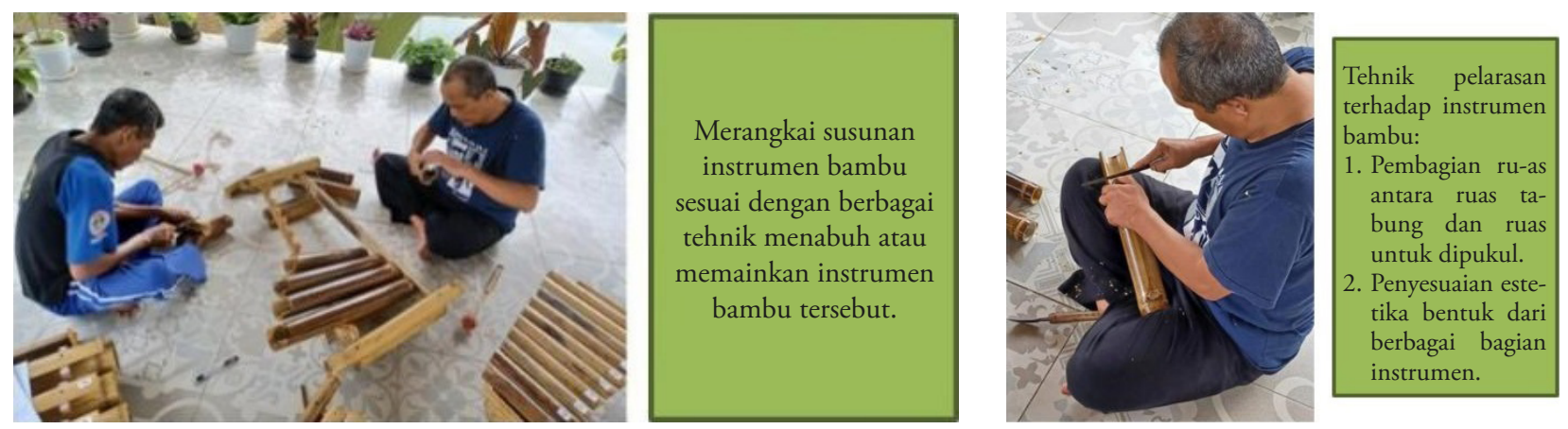

Gambar 29: Eksplorasi pembentukan instrumen bambu. (Dok. 2021)
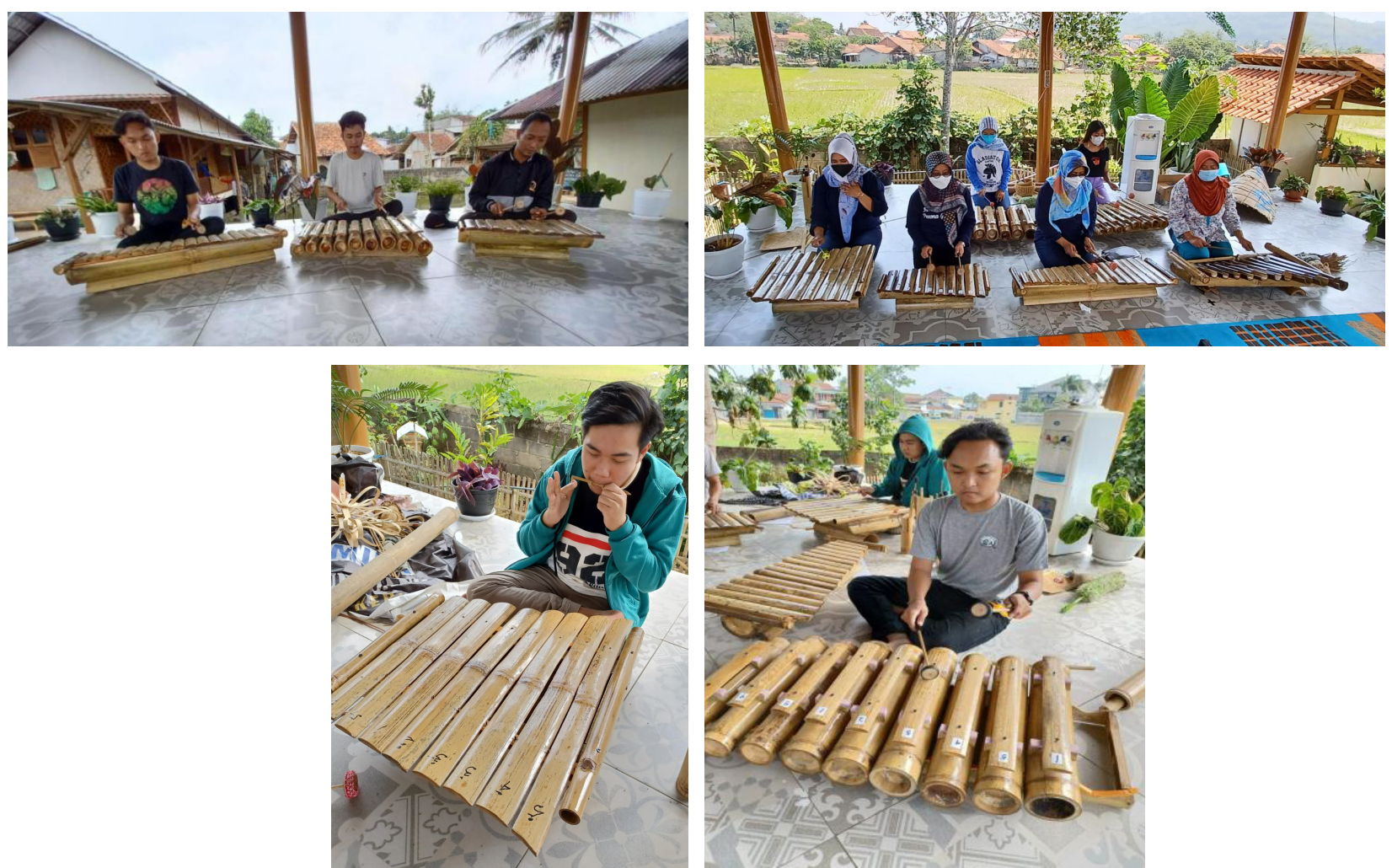

Gambar 30: Eksplorasi bunyi instrumen bambu. (Dok. 2021) 


\section{Kesimpulan}

Peneliti berupaya untuk menjadi duta diplomasi budaya terhadap masyarakat dalam memanfaatkan tanah hutan sosial untuk dimanfaatkan ekonominya dan dipadukan dengan kekayaan seni budaya. Komodivikasi bambu bermediakan penciptaan musik bambu adaptasi dari naskah kuno di kawasan perhutanan sosial.

Solusi yang diperoleh merupakan gabungan dari mitologi rakyat yang berbentuk naskah kuno yang terkait dengan Bambu sebagai penghasil sumber alam yang potensial di 3 (tiga) daerah ini, yaitu di Provinsi Jawa Barat, Daerah Istimewa Yogyakarta (DIY), dan Nusa Tenggara Timur (NTT). Komunitas ketiga wilayah tersebut, masyarakatnya dipandang memiliki tradisi bambu yang cukup kuat dan mempunyai kawasan perhutanan sosial.

Kesamaan akan adat istiadat atau kebiasaan masyarakat daerah-daerah tersebut dengan bambu, dijadikan embrio dalam tatanan konseptual. Sebagai pijakan awal diambil manuskrip-manuskrip, yang tentunya dianalisis dari berbagai sumber, meliputi; studi pusaka, observasi, wawancara, dokumenasi audio visual mengenai budi daya bambu, seni (instrumen), budaya, dan instalasi-instalasi tradisi bambu di lingkungan masyarakat tersebut.

\section{Kepustakaan}

Bakkers SJ. (1989). Filsafat Kebudayaan, Sebuah Pengantar. Yogyakarta: Penerbit Kanisius.

Barker, C. (2004). Cultural Studies:Teori dan Praktik. Yogyakarta: Kreasi Wacana.

Boissevain, J. (1996). Coping With Tourism European Reactions to Mass Tourism Published (July 1996). New Directions in Anthropology.

Cavallaro, D. (2004). Critical and Cultural Theory. Teori Kritis dan Teori Budaya. Yogyakarta: Penerbit Niagara.

Colletta, N. J. (1987). "Pendahuluan". Dalam Nat J. Colletta dan Umar kayam (ed.). Kebudayaan dan Pembangunan Sebuah Pendekatan terhadap Antropologi Terapan di Indonesia. Jakarta: Yayasan Obor Indonesia.

Cundaningsih, Nurvita, dkk. (2015). Kajian
Ekologi Bambu Hitam Bahan Baku Angklung di Jawa Barat. PROS SEM NAS MASY BIODIV INDON, 1(7), 1600-1604.

Damsar. (2015). Teori Sosiologi. Jakarta: Prenadamedia Group.

Dove, M. R. (1985). "Pendahuluan". Dalam Michael R. Dove (ed.). Peranan Kebudayaan Tradisional Indonesia dalam Modernisasi. Jakarta: Yayasan Obor Indonesia.

Dransfield; E.A. Widjaya. (1995). Plant Resources of South-East Asia no.7, Bamboos. Bogor: Prosea.

Edmund Husserl. (1972). The Encyclopedia of Philosophy, Vol. III. Ed. Paul Edward. (London $\&$ New York: Collier Macmillan Publisher.

Ervina Dewi, V. (2019). Transformasi Musik Tradisional Rinding Gumbeng Perspektif Postkolonial. Virtuoso (Jurnal Pengkajian Dan Penciptaan Musik), 2(2), 63-70.

Hasbiansyah, o. (2005). Pendekatan Fenomenologi: Pengantar Praktik Penelitian dalam Ilmu Sosial. Mediator, 9(1).

Heryanto, Y., Mauliani, L., \& Lissimia, F. (2017). Pusat Kesenian Angklung dengan Arsitektur Sunda Di Kota Bandung. Jurnal Arsitektur PURWARUPA Volume 01 No 2 September 2017, 1(2), 41-46.

Kusumaatmadja, S. (1995). "Sumbangan Kearifan Tradisional terhadap Upaya Kelestarian Lingkungan Hidup: Sebuah Pengantar". Analisis, XXIV(6), 410-413.

Kutha Ratna, N. (2005). Sastra dan Cultural Studies. Yogyakarta: Pustaka Pelajar.

Langer, S. K. (1976). Philosophy in a New Key: A Study in the Symbolism of Reason, Rite, and Art, third edition. Harvard University Press, Cambridge, Massachusetts.

Moelyono, M. (2010). Menggerakkan Ekonomi Kreatif: Antara Tuntutan dan Kebutuhan. Jakarta: PT Rajagrafindo.

Mosco, V. (2009). The Political Economy of Communication: Second Edition. London: Jage.

Mulyanto, D. (2012). Mulyanto, Dede. 2012. Genealogi Kapitalisme: Antropologi dan Ekonomi Politik Pranata Eksploitasi Kapitalistik. Yogyakarta: Resist Book.

Nadya, E. A., \& Winarto, E. D. (2019). 
Pengembangan Desa Wisata Pengrajin Bambu Yogyakarta dengan Pendekatan Localism. BORDER Jurnal Arsitektur, 1(1), 41-50.

Peraturan Menteri Kahutanan No. 35. (2007).

Peraturan Menteri Kehutanan Nomor P.35/ MENHUTII/2007 tentang Hasil Hutan Bukan Kayu.

Piliang, Y. A. (2005). Transpolitika: Dinamika Politik di Dalam EraVirtualitas. Yogyakarta: Jalasutra Yogyakarta: Jalasutra.

Pitana, I Gede dan Gayatri, P. G. (2005). Sosiologi Pariwisata: Kajian Sosiologi terhadap Struktur, Sistem, dan Dampak-Dampak Pariwisata. Yogyakarta: Andi.

Rao, Ramanuja, B. Sastry, Cherla, Widjaja, E. (1996). Bamboo, People and The Environment. Congress. Ubud, Bali, Indonesia, 19-22 June 1995.

Rigg, J. (1986). A dictionary of the Sunda language of Java (Vol. 29). Batavia: Lange \&amp; Co, 1802.

Rossle M. And Cleere, H. (2001). Cultural Landscapes, dalam World Conservation: Vision and Reality, The World Heritage Convention. IUCN, Rue Mauverney 28, CH-1196 GlandSwitzerland.

Saepudin, A. (2017). Gamelan Awi di Cineam Tasik Malaya sebagai Media Alternatif Pembelajaran Karawitan Sunda. Awi Laras, 4(2), 78-107.

Scheffler. (1977). Symbolic Worlds: Art, Science, Language, Ritual by I. Scheffler. Review by: Jens Brockmeier. The Journal of Educational Thought (JET) / Revue de La Pensée Éducative, 32(3), 296-299.

Spradley, J. P. (1997). Metode Etnografi. Yogyakarta: PT Tiara Wacana Jogya.

Susanti, Santi, Sjuchro, D. W. (2019). Saung Angklung Udjo: Wisata dan Pelestarian Budaya. Jurnal Ilmu Politik Dan Komunikasi, IX(2), 35-43.

Susanti1, S., Koswara, I., \& Rachmaniar. (2020). Komunikasi Pemasaran Kerajinan Bambu di
Selaawi, Kabupaten Garut, Jawa Barat. Jurnal Lensa Mutiara Komunikasi, 4(2), 39-55.

Tedjasendjaja, G. A., \& Dharmadi, S. (2015).

Kajian Pelestarian Alat Musik Angklung Dalam Bentuk Kampanye Sosial. RUPARUPA, 4(2), 109-117.

Turner, V. (1967). The Forest of Symbol. Ithaca, N.Y: Cornell University Press.

Undang-Undang Nomor 41. (1999). UndangUndang Nomor 41 Tahun 1999 tentang Kehutanan (Lembaran Negara Republik Indonesia Tahun 1999 Nomor 167 (p. 167).

Unesco. (1999). Convention Concerning The Protection of The World Cultural and Natural. Paris: Heritage.

Upaja Budi, Dinda Satya, Soedarsono, RM, Haryono, Timbul, Narawati, T. (2014). Angklung Dogdog Lojor Pada Upacara Seren Taun. Resital: Jurnal Seni Pertunjukan, 15(2), 139-151.

Upaja Budi, D. S. (2017). Modifikasi Angklung Sunda. Resital: Jurnal Seni Pertunjukan, 18(1), 43-52.

White. (1969). The Science of Culture: A Study of Man and Civilization. New York, N.Y.: Grove.

Widjaja, E. A. (2013). Diskusi dalam acara Merajut Bambu. Pendapa, Bale Tingal, Borobudur Magelang, April 2013.

\section{Daftar Narasumber}

Mujimin, 46 tahun, pengrajin berbahan bambu dari Nabin RT. 22/10 Sidomulyo Pengasih, Kulonprogo.

Silvester, 32 tahun, Staf Pegawai Pemerintahan Larantuka.

Sri Hartini, 48 tahun. Pimpinan Rinding Gumbeng Ngudi Laras, Ngawin Gunung Kidul.

Sujarwanto, 57 tahun, pimpinan Grup Srawung Krumpyung, dari Sremo Tengah, Dusun Hargowilis Kecamatan Kokap, Kulonprogo. 